Cheilostome Bryozoa of

Late Eocene Age From

Eua, Tonga

GEOLOGICAL SURVEY PROFESSIONAL PAPER 640-E 
Cheilostome Bryozoa of

Late Eocene Age From

Eua, Tonga

By ALAN H. CHEETHAM

LATE EOCENE FOSSILS FROM EUA, TONGA

GEOLOGICAL SURVEY PROFESSIONAL PAPER 640-E

Mixed assemblage of shallow- and deep-sea species

from offreef tuffaceous limestone

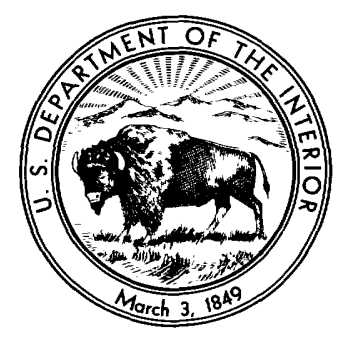

UNITED STATES GOVERNMENT PRINTING OFFICE, WASHINGTON : 1972 


\section{UNITED STATES DEPARTMENT OF THE INTERIOR}

ROGERS G. B. MORTON, Secretary

\section{GEOLOGICAL SURVEY}

W. A. Radlinski, Acting Director

Library of Congress catalog-card No. 70-181826

For sale by the Superintendent of Documents, U.S. Government Printing Office Washington, D.C. 20402 - Price 70 cents (paper cover)

Stock Number 2401-1203 


\section{LATE EOCENE FOSSILS FROM EUA, TONGA-FOREWORD}

One of the most widespread units of the Cenozoic section in the islands of the open Pacific is a series of limestones assigned to the upper Eocene (Tertiary b). Such limestones, containing diagnostic larger Foraminifera, have been reported in many parts of an area spreading 4,000 miles across the tropical Pacific (fig. 1), from Palau and the Mariana Islands on the northwest through the Marshall Islands (Eniwetok) to Fiji and Tonga on the southeast (Whipple, in Hoffmeister, 1932, p. 79-86; Asano, 1939; Cole, 1950, 1957a, 1957b, 1960). In almost all the islands the limestones are dense and crystalline. Foraminifera and algae are abundant locally, but in most places fossils cannot be extracted and must therefore be studied in random thin sections. On the little island of Eua, Tonga, a locality was recently found where the Eocene limestone is tuffaceous, considerably weathered, and richly fossiliferous. Abundant fossils that represent a dozen organic groups were found. Such abundance and diversity signaled the find as a remarkable one that would add greatly to our knowledge of life in the western Pacific during the Eocene.

The island of Eua measures only 12 by 5 miles but it rises 1,000 feet above sea level. It occupies an interesting position tectonically, as its steep eastern side faces the Tonga Trench. In addition, Eua is the oldest island in the Tonga group that has a plutonic core (Guest, 1959) and a series of associated volcanic rocks, which are partly blanketed by thick limestones of late Eocene age. Younger volcanic rocks and sediments of late Tertiary age are also present (Hoffmeister, 1932).

This series of reports is concerned with one facies of the upper Eocene limestone. After the limestone series was deposited, Eua was uplifted periodically and a sequence of six terraces was cut in the limestones on the windward (eastern) side. Hoffmeister was the first to recognize the Eocene age of the main limestone of the terraces, three of which have veneers of Pliocene reef corals. He made a planetable map of the terraced eastern ridge and recorded the average altitudes of the terraces as $100,200,340,400,550$, and 760 feet. The east-facing "rocky backbone" of Eua thus looks in profile like a giant staircase facing the Tonga Trench. The Eocene limestone may once have covered all of Eua but is now largely limited to the eastern ridge (Hoffmeister, 1932; the Eocene Foraminifera were described by Whipple in this same report, p. 79-86).

The fossils described in this series of reports were obtained from an outcrop on the 400-foot terrace about a quarter of a mile north of Vaingana (fig. 2). At this locality, the limestone lies close to the underlying volcanic rock and is tuffaceous and pertly weathered; almost everywhere else on Eua the limestone is pure, hard, and crystalline.

In 1943, Harold T. Stearns, then of the U.S. Geological Survey, also served as a consultant to the Armed Forces at Pacific bases and made a brief visit to Eua. He collected a sample that contained half a dozen fossil brachiopods from the 400-foot terrace on the eastern side of the island. Stearns recorded the locality as: "Tele-a-hiva at elevation of 400 feet about $1 / 2$ mile north of army lookout tower, at the second stream north of Vaigana [sic]." The brachiopods were examined by G. A. Cooper of the U.S. National Museum. Some years later when I was studying other island fossils collected by Stearns, Cooper showed me the brachiopods and expressed a desire for additional specimens so that he could continue his study of their internal structures.

In 1966, I learned that Yoshio Kondo of the Bernice P. Bishop Museum in Honolulu intended to visit Eua in connection with his studies of living Pacific island land snails (under National Science Foundation grant GB-3974). I sent Stearns' locality data and marked copy of Hoffmeister's Eua map to Kondo, and I informed Stearns of the plan to collect additional material.

Late in August 1967, Ḱondo reached Eua and, aided by a Tongan guide, Tomiki, and an interpreter, Mosese Vea, spent 2 days searching for the fossil locality. The lookout tower mentioned by Stearns no longer exists and Kondo found that Tele-a-hiva translates to "Nine Gulches." Traveling northward from "Vaigana" (Otu Vaingana) through heavy brush on exceedingly rugged karst topography for about 1,000 feet, he reached the first of the gulches. There he found a soft fossiliferous layer between two harder limestones and collected a 
40-pound sample of the material. This gulch locality is probably not the exact spot visited by Stearns. The two collections have minor differences in nature of preservation, but they obviously came from the same formation.
In 1969 Wilfred Bryan of the Carnegie Institution of Washington collected additional material from the locality sampled by Kondo. Bryan's material was taken from soft calcareous tuffs 2-3 feet in thickness that dipped $30^{\circ}-40^{-} \mathrm{E}$. These calcareous tuffs were

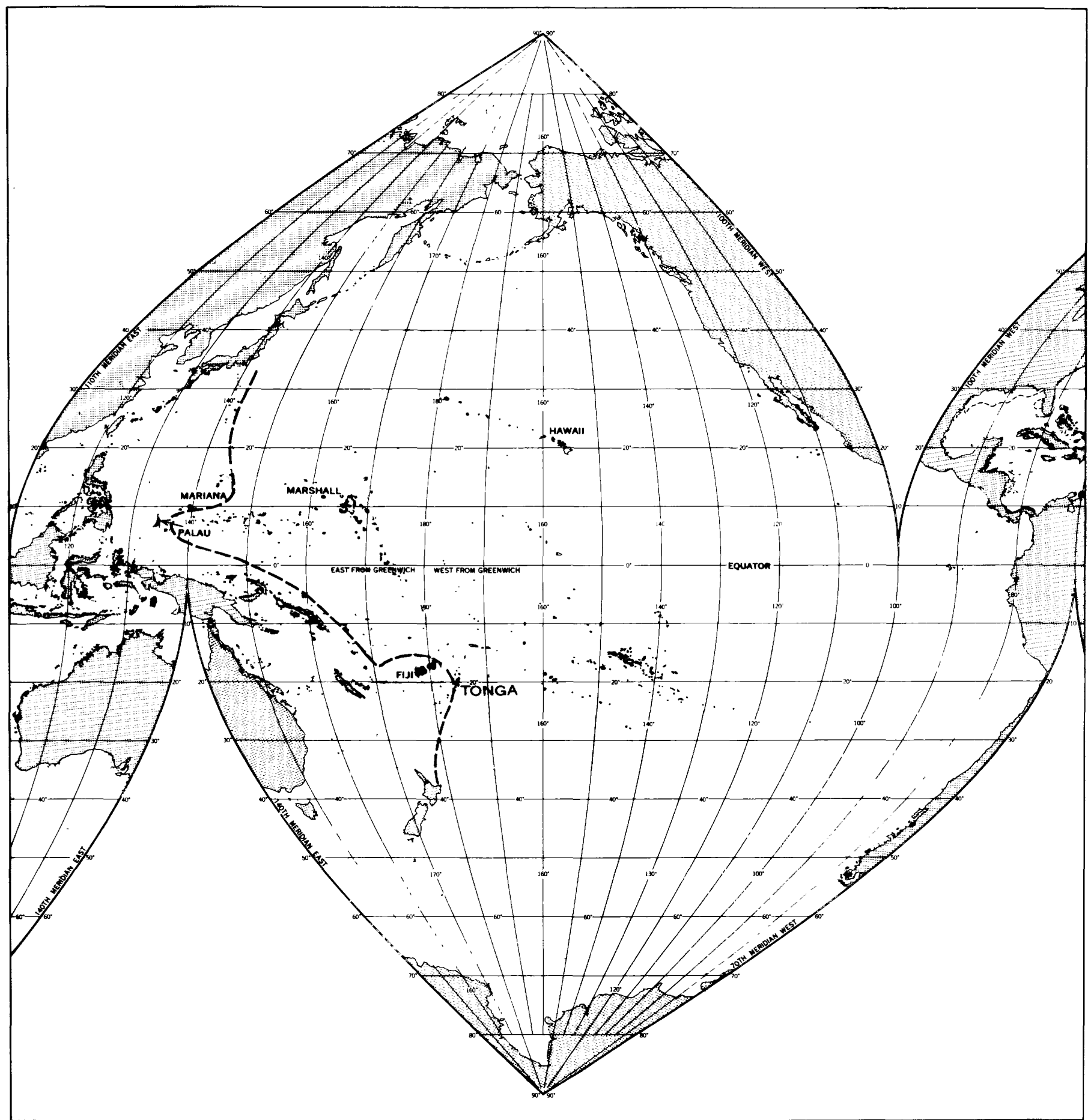

FIGURE 1.-Location of Tonga and other island groups in the southwest Pacific where upper Eocene limestone has been identified. Dashed line marks structural boundary of the Pacific Basin (andesite line). Islands shown include the surrcunding reefs. 
directly underlain by several feet of harder fossiliferous material that, in turn, lay above agglomerate with truncated dikes. The horizon sampled was at an altitude of about 355 feet in a gully notched into the 400-foot terrace.

The exact extent of the richly fossiliferous bed is not known. In 1926, when Hoffmeister made his

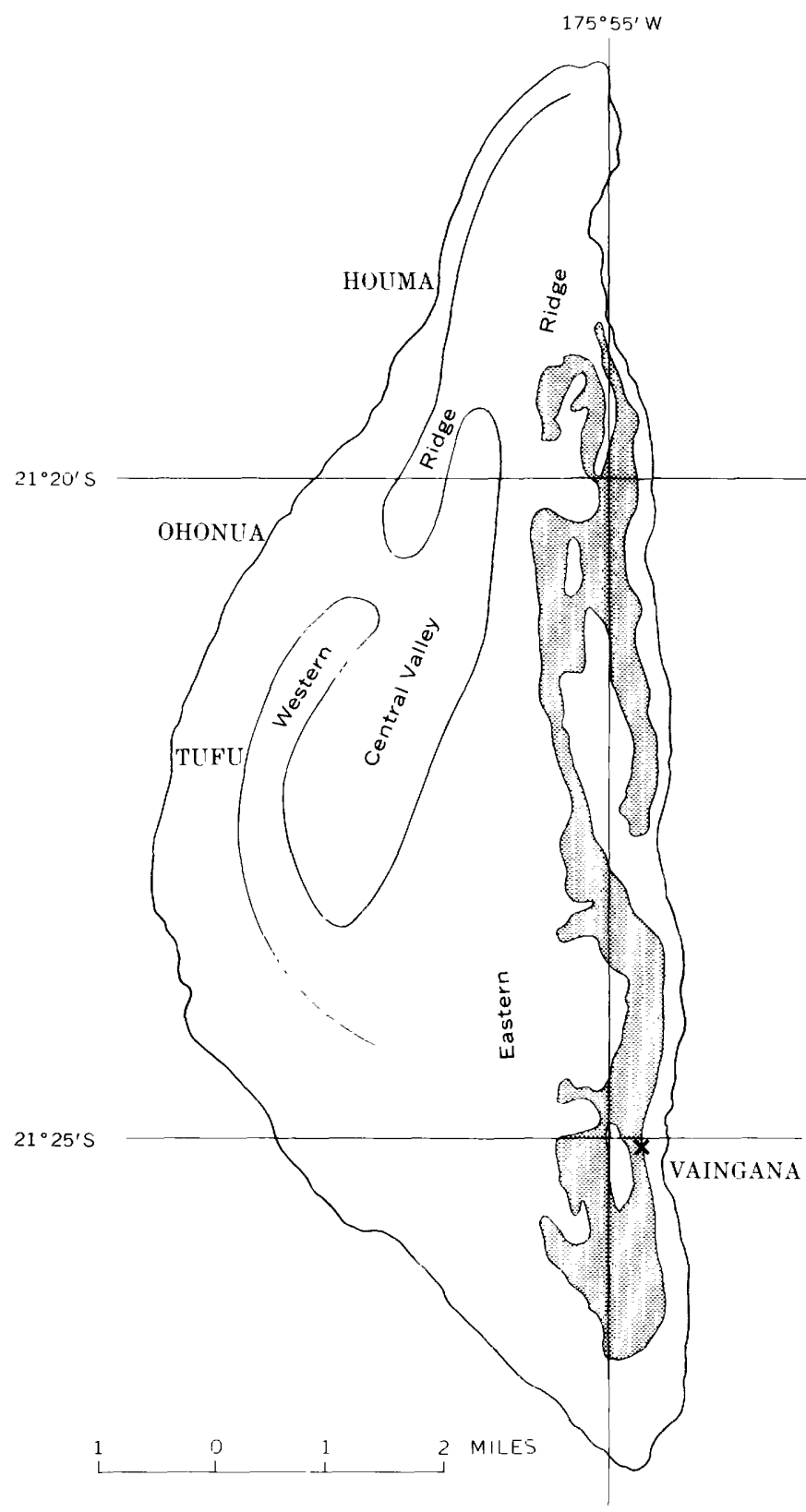

Figure 2.-Map of Eua, Tonga, showing the location of the recently discovered fossil outcrop $(X)$ and the main mass of Eocene limestone (patterned area) on the east side of the island, as mapped by Hoffmeister (1932). map of the terraces, he did not come upon this facies, and in 1928 when I spent 2 weeks on Eua with Hoffmeister, reviewing his mapping, no exposures of this zone were seen although we visited Vaingana. Additional fieldwork in the area of the rugged "Nine Gulches" would be worthwhile.

William Melson of the Smithsonian Institution examined hand specimens and thin sections of the tuffaceous limestone and noted that the volcanic constituents are highly altered, making it difficult to determine their original nature. The rock is composed of 50 percent or more of volcanoclastic debris, much of which has been replaced by calcite. The predominant volcanic fragments are of porphyritic pumiceous glassy material; most of the phenocrysts are plagioclase, now largely replaced by calcite. The original groundmass of pumiceous glass is row devitrified and dark brown. Fragments of tuff are rare. There appears to be a large and varied assemblage of secondary minerals. The volcanic fragments are mainly porphyritic andesitic rocks, or possibly plagioclase-bearing dacites. The presence of abundant fossils suggests that the volcanic material has been reworked.

The soft tuffaceous limestones collected on J'ua were treated with a wetting agent and penetrant in the laboratory. The material broke down easily, revealing a variety of fossil remains: Foraminifera, discoasters, corals, hydrozoans, brachiopods, bryozoans, annelids, crinoids, echinoids, ostracodes, barnacles, decapod crustaceans, mollusks, shark teeth, otoliths, and spores and other plant microfossils.

W. Storrs Cole has described the larger Foraminifera; these fossils suggest to him a depth of dep sition of about 200 feet, but other groups-notably the smaller Foraminifera, the corals, brachiopods, bryozoans, mollusks, ostracodes, and barnacles-point to a considerably greater depth of deposition.

Material representing a total of 17 organic groups was distributed to paleontologists for study and report. Seven of these collections were small or wore made up of incomplete specimens leading only to summary reports, but the others, except for the larger Foraminifera, contained much new material. The brachiopod, bryozoan, ostracode, barnacle, and mollusk collections contained the first identifiable Eocene species from the islands of the open Pacific, an area extending 4,000 miles from Palau to Torga.

HARRY S. LAD? 



\section{CONTENTS}

Foreword

Abstract

Introduction

Paleoenvironments

Distribution of Tetraplaria

Distribution of Bifaxaria

Distribution of Tessaradoma

Tongan cheilostome faunal elements.

Morphology of deep-water species

Systematic paleontology

Chaperiidae

Patsyella?

Cellariidae Cellaria

Bicellariellidae Beania

Scrupocellariidae

Canda

Menipea

\begin{tabular}{r|} 
Page \\
III \\
E1 \\
1 \\
2 \\
2 \\
4 \\
6 \\
6 \\
7 \\
8 \\
8 \\
8 \\
8 \\
8 \\
9 \\
9 \\
9 \\
9 \\
10
\end{tabular}

Cribrilinidae Figularia?

Exechonellidae

Triporula

Bifaxariidae Bifaxaria

Spiroporinidae Spiroporina

Tessaradoma

Siphonicytaridae Tubitrabecularia

Sertellidae Reteporellina?

Schizoporellidae

Schizoporella

Chiastosella?

Tetraplariidae

Tetraplaria

References cited

Index
Page

E10

10

11

11

11

11

14

14

\section{ILLUSTRATIONS}

[Plates follow index]

Plate 1. Canda, Patsyella?, and Cellaria.

2. Figularia?, Menipea, Beania, and Triporula.

3. Bifaxaria.

4. Bifaxaria, Chiastosella?, and Spiroporina.

5. Spiroporina, Schizoporella, and Tessaradoma.

6. Reteporellina? and Tubitrabecularia.

7. Tetraplaria.

FIGURE 1. Map showing the location of Tonga and other island groups in the southwest Pacific where upper Eocene limestone has been identified.

2. Map of Eua, Tonga, showing the location of the recently discovered fossil outcrop and the main mass of Eocene limestone

3. Map showing worldwide geographic and stratigraphic distribution of Tetraplaria

4. Graph showing depth-latitude distribution of living species of three genera of cheilostome Bryozoa represented in upper Eocene beds on Eua, Tonga.

5. Map showing worldwide geographic and stratigraphic distribution of Tessaradoma

6. Graph showing variations in width of successive pairs of autozooecia and distal kenozooecia in five internodes of Tetraplaria simata, n. sp.

7. Graph showing variations in length of successive pairs of autozooecia and distal kenozooecia in five internodes of Tetraplaria simata, n. sp.

\section{TABLE}

TABLE 1. Specimen abundance, other properties of cheilostome bryozoan species in two samples from upper Eocene beds on Eua, Tonga 



\title{
CHEILOSTOME BRYOZOA OF LATE EOCENE AGE FROM EUA, TONGA
}

\author{
By Alan H. Cheetham ${ }^{1}$
}

\begin{abstract}
An assemblage of cheilostome Bryozoa from upper Eocene (Tertiary $b$ ) beds on Eua, Tonga, appears to be a mixture of five autochthonous and 13 allochthonous species. The autochthonous element, which makes up about 85 percent of the specimens in the assemblage, includes the first known fossil cryophilic deep-sea cheilostomes. It can be inferred that these species have lived in water cooler than $13^{\circ} \mathrm{C}$ at a depth that in the tropics or subtropics exceeded 200 meters. The much rarer but more diversified allochthonous element includes some thermophilic taxa that probably lived at depths less than 100 meters in water having an average temperature of not much less than $20^{\circ} \mathrm{C}$ in the coolest months. At least some of the allochthonous species grew attached to nonbouyant substrates and therefore must have been transported to the burial site from a shallow-bottom habitat.

In contrast to the allochthonous species, which show a variety of colony forms, all the inferred deep-water species had nonfenestrate, rigidly erect, subcylindrical to compressed, branched colonies probably attached to the substrate by encrusting bases. Outer skeletal walls probably thickened throughout life; this accretion allowed proximal trunks and branches to thicken greatly and suggests that the colonies grew up from the substrate to filter food from the water, much as do shelf species having similar colonies.

Seven new species, four autochthonous and three allochthonous, are described. Additional allochthonous material seems identifiable with five species known from deposits of middle Eocene to early Miocene age in Australia or India. The remaining material, apparently belonging to six genera, is inadequate for assignment to species.
\end{abstract}

\section{INTRODUCTION}

An assemblage of 18 species of cheilostomes from upper Eocene (Tertiary $b$ ) beds on Eua, Tonga, includes the first known fossil deep-sea Bryozoa. The five species inferred to be part of this deep-water faunal element belong to four ascophoran genera, and four of the species are morphologically closely comparable to congeneric Holocene deep-sea species. A significant evolutionary history in the deep sea thus probably preceded the entombment of deepwater cheilostomes in sediments now cropping out

\footnotetext{
I Department of Paleobiology, National Museum of Natural History, Smithsonian Institution, Washington, D.C. 20560
}

in Tonga. The species in this faunal element all had nonfenestrate, rigidly erect, subcylindrical to slightly flattened, branched colonies, in which calcar?ous accretion seemingly continued throughout life to thicken markedly the more proximal branches. If sinitar heavily calcified zoaria characterize deepwate species generally, then other deep-water assemblatges may be preserved in Tertiary deposits.

In addition to the deep-water element, 13 species occuring less commonly in the assemblage are irferred to have been transported to the site of burial from a shallow-bottom, tropical or subtropical habitat, probably not on a reef. These species belong to genera that are common in Tertiary deposits in the Australia-New Zealand region, and some of the genera have virtually circumtropical distributions. Tongan specimens are identifiable with the following four Australian Tertiary species: Cellaria cucullata MacGillivray, from the upper Eocene Glenaulin Clay and Cape Otway beds of Brown (1958) ; and Canda fossilis Waters, Menipea innocua Waters, and Tubitrabecularia clypeata (Waters), from the lower Miocene Balcombian Stage. Tongan material also seems identifiable with Tetraplaria turgida Tewari and Srivastava, a species described from the middle Eorene Kirthar Stage of India.

Specimens of both shallow- and deep-water species are poorly preserved; a few inferred shallow-water specimens show abrasion. The material is from two samples collected from approximately the same outcrop about one-quarter mile north of Vaingana, Eua, Tonga (see "Foreword" and fig. 2), at 400 feet altitude. The samples are listed separately in $\operatorname{tal}^{1} \mathrm{e}, 1$ (sample 1, station 24686, collected by Y. Kondo, 1967 ; sample 2, station 24745 , collected by Wi]fred Bryan, 1969) ; the differences between them apnear to be within the expected sampling error. The material has been dated by Cole (1970) as late Eocene, and by Todd (1970) as from the Globigerina gortanii planktonic foraminiferal zone. 
A less abundant assemblage of cyclostome Bryozoa in the same samples has not been studied.

I am indebted to Harry S. Ladd for the specimens on which this study is based and for comments on the manuscript; to Richard S. Boardman and Joseph E. Hazel for critical reviews of the manuscript; and to JoAnn Sanner and Lorenzo Ford for valuable technical assistance.

\section{PALEOENVIRONMENTS}

In the absence of living species in this assemblage, the conditions under which it lived and was buried can be inferred only from the geographic and bathymetric ranges of living congeneric species. All the Tongan Eocene species but one, Tubitrabecularia clypeata, have living congeners.

The geographic and bathymetric ranges of genera can, of course, be equal to those of each included species, but in general they are appreciabl' greater. It is not surprising, therefore, that nine of the $\mathbf{1 5}$ genera represented, or probably represented, in the Tongan Eocene assemblage include living species whose composite ranges extend more thar $45^{\circ}$ latitudinally from the equator and from shallow depths to 200 meters or more, with shallow occurrences at both low and middle latitudes. These eurrthermal, eurybathic genera-Beania, Cellaria, Chiastosella, Figularia, Menipea, Patsyella, Reteporellina, Schizoporella, and Spiroporina-account for more than half the species and about 60 percent of the specimens in the assemblage (table 1). The Tongan species of two of these genera, however, are morphologically closely similar to living species having much more restricted ranges, as discussed below.

TABLE 1.-Specimen abundance, other properties of cheilostome bryozoan species in two samples from upper Eocene beds on Eua, Tonga

[Estimated temperature tolerances are based on depth-latitude distribution of morphologically similar living species]

\begin{tabular}{|c|c|c|c|c|}
\hline \multirow[b]{2}{*}{ Species } & \multicolumn{2}{|c|}{ Number of samples } & \multirow{2}{*}{$\begin{array}{c}\text { Temperature } \\
\text { tolerance }\end{array}$} & \multirow{2}{*}{$\begin{array}{l}\text { Irferred } \\
\text { growth } \\
\text { form }\end{array}$} \\
\hline & Sample 1 & Sample 2 & & \\
\hline Spiriporina kondoi, n. sp. & 74 & 10 & Cryophilic & Vincula xiiform \\
\hline Bifaxaria diaphyota, n. sp. & 31 & 19 & do & Do. \\
\hline Reteporellina? sp. & 12 & 7 & Eurythermal & Eschariform \\
\hline Bifaxaria bryani, n. sp. & 2 & 4 & Cryophilic & Vincula xiiform \\
\hline Tubitrabecularia clypeata (Waters) & 5 & 0 & Eurythermal & Do. \\
\hline Tetraplaria simata, n. sp. & $\begin{array}{l}\ldots \\
\ldots \ldots\end{array}$ & 2 & Thermophilic & Cellariiform \\
\hline Spiroporina deliqua, n. sp...... & 5 & 0 & do & Vinculariform \\
\hline Tessaradoma bifax, n. sp. & 3 & 1 & Cryophilic & Do. \\
\hline Canda fossilis Waters & 0 & 4 & Thermophilic & Retepol'iform \\
\hline Tetraplaria cf. T. turgida Tewari and Srivastava & 0 & 3 & 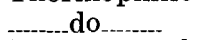 & Cellariiform \\
\hline Schizoporella aff. S. macgillivrayi Canu and Bassler & 2 & 0 & Eurythermal & Vinculariform \\
\hline Beania diademata, n. sp. & ..... & 1 & Thermophilic & Petraliiform \\
\hline Cellaria cucullata MacGillivray & - & 0 & Eurythermal & Cellariiform \\
\hline Chiastosella? sp. & 0 & 1 & do & Membraniporiform \\
\hline Figularia? sp. & 0 & $\overline{1}$ & do & Vinculariiform \\
\hline Menipea innocua Waters & 0 & 1 & do & Eschar form \\
\hline Patsyella? sp. & 1 & 0 & do & Vincula riiform \\
\hline Triporula aff. T. biarmata (Waters) & 0 & 1 & Thermophilic & Membraniporiform \\
\hline
\end{tabular}

Five of the genera represented in the Tongan assemblage have Holocene depth-latitude distributions suggesting stenothermal tolerances. The known occurrences of Canda (see Harmer, 1926). Tetraplaria (see below), and Triporula (see Cook, 1967) are consistent with a thermophilic restriction to shoalwater, tropical or subtropical habitats. On the other hand, Bifaxaria seems to be cryophilic, occurring chiefly, perhaps exclusively as discussed below, at bathyal and abyssal depths. Tessaradoma appears to be unique among the genera in this assemblage in being cryophilic with extremely broad latitudinal and bathymetric ranges.

A paleoenvironmental interpretation of the Tongan assemblage thus depends upon the seemingly anomalous association of the cryophilic genora Bifaxaria and Tessaradoma with thermophilic genera exemplified by Tetraplaria. The importance of the Holocene distributions of these genera and the expectation that their Eocene distributions conforned to the same thermal control necessitate more detailed discussion than is available in previous literature.

\section{DISTRIBUTION OF TETRAPLARIA}

The living species of Tetraplaria are cistributed nearly circumtropically (fig. 3 ). The on] 7 tropical region in which the genus has not been found is the West African province, the cheilostome fauna of which has been extensively studied (see Ccok, 1968). 


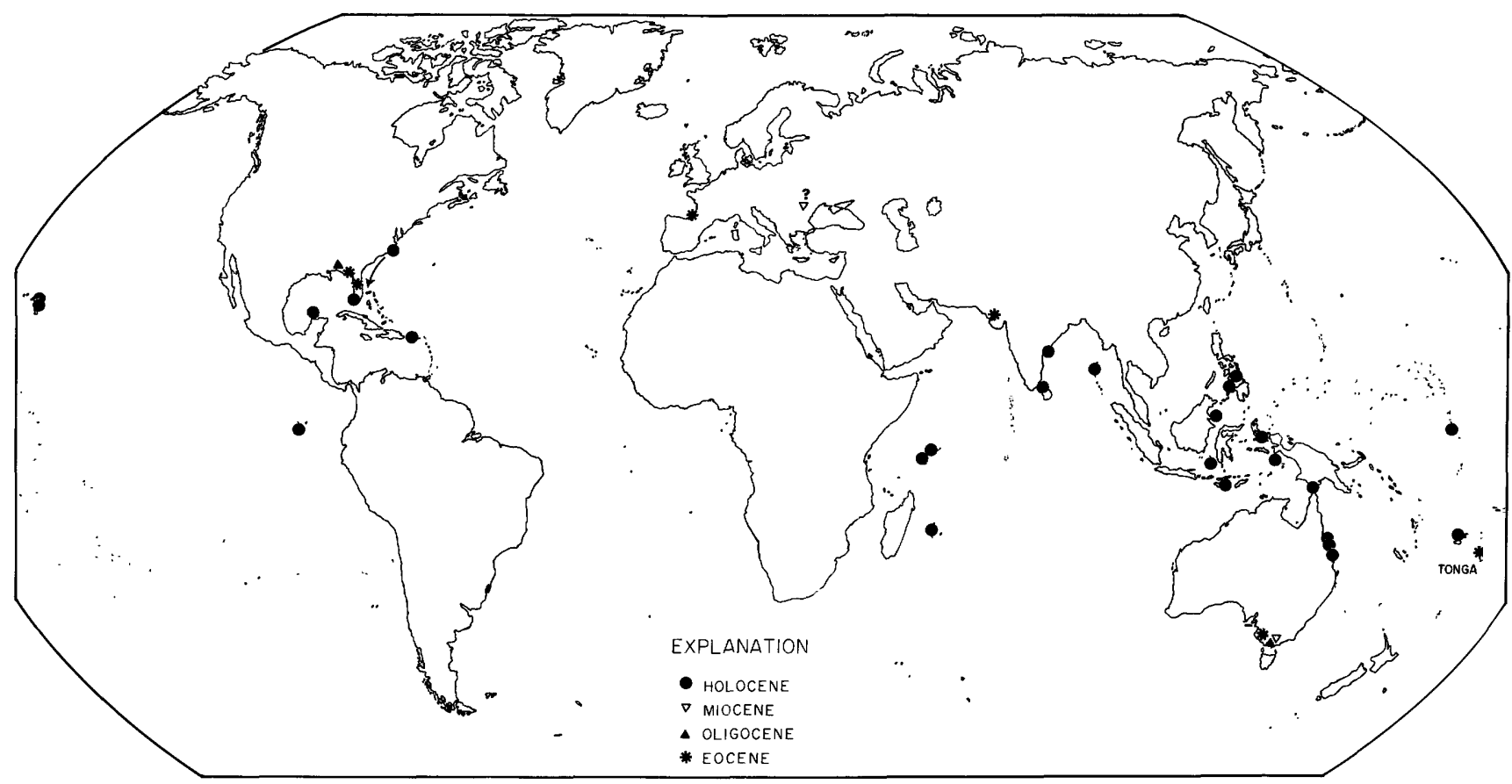

Figure 3.-Geographic and stratigraphic distribution of Tetraplaria. Sources of data are Brown (1958), Canu and Bassler (1920, 1928b, 1929), Cheetham (1959; 1963), Ghiurca (1966), Harmer (1957), Haswell (1880), Kirchenpauer (1869), Kirkpatrick (1888), Labracherie (1968), MacGillivray (1895), Maplestone (1900, 1909), Maturo (1968), Osburn (1914, 1940, 1952), Robertson (1921), TenisonWoods (1879), Tewari and Srivastava (1967), Thornely $(1905,1907)$, Waters $(1881,1883)$, and the following addi- tional specimens in the collections of the National Museum of Natural History, Smithsonian Institution: Tetraplaria sp. (Oligocene, Marianna Limestone, St. Stephens quarry, Ala.) ; T. tuberculata (upper Eocene, Crystal River Limestone of Cheetham (1963), Sepulga River bridge, Broolyn, Ala.) ; T. australis (Oligocene, Janjukian Stage, Bird Rock, Torquay near Geelong, Victoria, Australia); T. australis (lower Miocene, Balcombian Stage, Altona Bay Coal Shaft, Port Phillips, Victoria, Australia).
The most widely distributed species is the IndoPacific T. ventricosa (Haswell), known under four names (Harmer, 1957), from the Amirante Islands and Seychelles (long $53^{\circ} 30^{\prime}$ E.) eastward to the Fiji Islands (long $178^{\circ} 45^{\prime} \mathrm{E}$.). All the known occurrences of $T$. ventricosa lie between latitudes $17^{\circ} \mathrm{N}$. and $20^{\circ}$ $\mathrm{S}$. Three more names (Pollaploecium gilbertensis Maplestone; $P$. brevis Canu and Bassler; and Tetraplaria veleroae Osburn) probably refer to a second species distributed from the Gilbert Islands (long $174^{\circ} \mathrm{E}$.) eastward to the Galapagos (long $90^{\circ} 30^{\prime} \mathrm{W}$.) and from just south of the equator to about latitude $20^{\circ} \mathrm{N}$. Two other species have constrastingly restricted distributions; the Atlantic T. dichotoma (Osburn) occurs only north of the equator (lat $17^{\circ} 55^{\prime}-24^{\circ} 45^{\prime}$ N.), whereas the Australian T. immersa (Haswell) is known only from the south (lat $9^{\circ} 55^{\prime}-21^{\circ} 39^{\prime} \mathrm{S}$.).

The thermal significance of the present latitudinal range of Tetraplaria is not known directly because bottom-temperature data are available for only one of the stations at which it occurs $\left(26^{\circ} \mathrm{C}\right.$ in April 1902 , at $36-38 \mathrm{~m}$, Albatross sta. D. 4168, Hawaii). All the modern occurrences are in areas where the surface waters average $20^{\circ} \mathrm{C}$ or more during the coolest month of the year. The Atlantic and Indian Ocean occurrences are all in shallow water, 11-18 m and 7-31 $\mathrm{m}$, respectively. Bottom-water temp?ratures at these depths are no doubt only slightly cooler than surface water temperature. The Pacific occurrences, however, are less restricted in depth, five reported at more than $50 \mathrm{~m}$ and three of thes? at more than $100 \mathrm{~m}$.

Two of the records at more than $100 \mathrm{~m}$, one in the Philippines (104 m; Canu and Bassler, 1929) and one in the Galapagos (110 m; Osburn, 1952), appear not to be extreme if compared with the shallower occurrences, but the third, between 147 and $183 \mathrm{~m}$ in the Galapagos (Osburn, 1952), may be outside the living range of the genus. The jointed colonies of $T e-$ traplaria readily disintegrate to form small, subcylindrical internodes that could be transported eesily down submarine slopes. Encrusting attachment bases of colonies, which probably are more difficult to transport, have been described for only two oc?urrences, one at $110 \mathrm{~m}$ in the Galapagos (Osburn, 1952) and the other at $13 \mathrm{~m}$ in Indonesia (Harmer, 1957). 
Because of the great morphological differences between zooecia making up the encrusting bases and zooecia in the erect parts of the colony, these bases may have been overlooked for some occurrences of the genus; it is unlikely, however, that this possibility would explain the depth difference in the two Galapagos occurrences, both reported by Osburn (1952).

The $20^{\circ} \mathrm{C}$ or warmer survival range suggested by the depth-latitude distribution of the living species can be applied to fossil species of Tetraplaria only in the absence of morphological and distributional evidence indicating evolutionary changes in temperature tolerance. The nearest known counterpart in distribution and morphology to the widespread Holocene Indo-Pacific species $T$. ventricosa is $T$. turgida Tewari and Srivastava, from the middle Eocene of India, which may be represented in the Tongan material. Other fossil species, however, give the genus an appreciably broader Eocene latitudinal range $\left(43^{\circ}\right.$ $29^{\prime}$ N. $-38^{\circ}$ S.) than it now has. Aside from $T$. simata, n. sp., in the Tongan Eocene, these species form two morphologically and distributionally distinct groups, one in the Eocene-Miocene of Australia ( $T$. australis Tension-Woods, T. pedunculata (MacGillivray)) and the other in the Eocene-Oligocene of the Atlantic and Gulf Coastal Plains (T. obesa Cheetham, T. petila Cheetham, T. tuberculata Canu and Bassler). The occurrence of a species apparently intermediate between the Australian and American groups in the Eocene of southwestern France ( $T$. sp. Labracherie, 1968) may record a Tethyan dispersal route between the two areas. The living American T. dichotoma, however, appears morphologically more closely related to T. turgida than to the American Eocene species. Thus it may represent a relict outlier of a oncecontinuous Indo-Pacific-western Atlantic relative of the two Indo-Pacific species. It seems unlikely, therefore, that the thermal significance of $T$. turgida was much different from that of living species of Tetraplaria, and the broader latitudinal distribution of the genus in the Eocene may be related to the generally broader tropical climatic belt of that time (see summary in Schwarzbach, 1963, p. 178-180).

\section{DISTRIBUTION OF BIFAXARIA}

The 14 nominal species of Bifaxaria as constituted here (see discussion p. E11) are only slightly less limited latitudinally than Tetraplaria (fig. 4). In the Atlantic five species occur between $38^{\circ} 25^{\prime} \mathrm{N}$. and $9^{\circ}$ $05^{\prime} \mathrm{S}$.; in the Pacific ten species are distributed from $38^{\circ} 09^{\prime} \mathrm{N}$. to $8^{\circ} 18^{\prime} \mathrm{S}$. Only one species, $B$. submucronata Busk, apparently is common to the two oceans (see Harmer, 1957; Hastings, 1966).

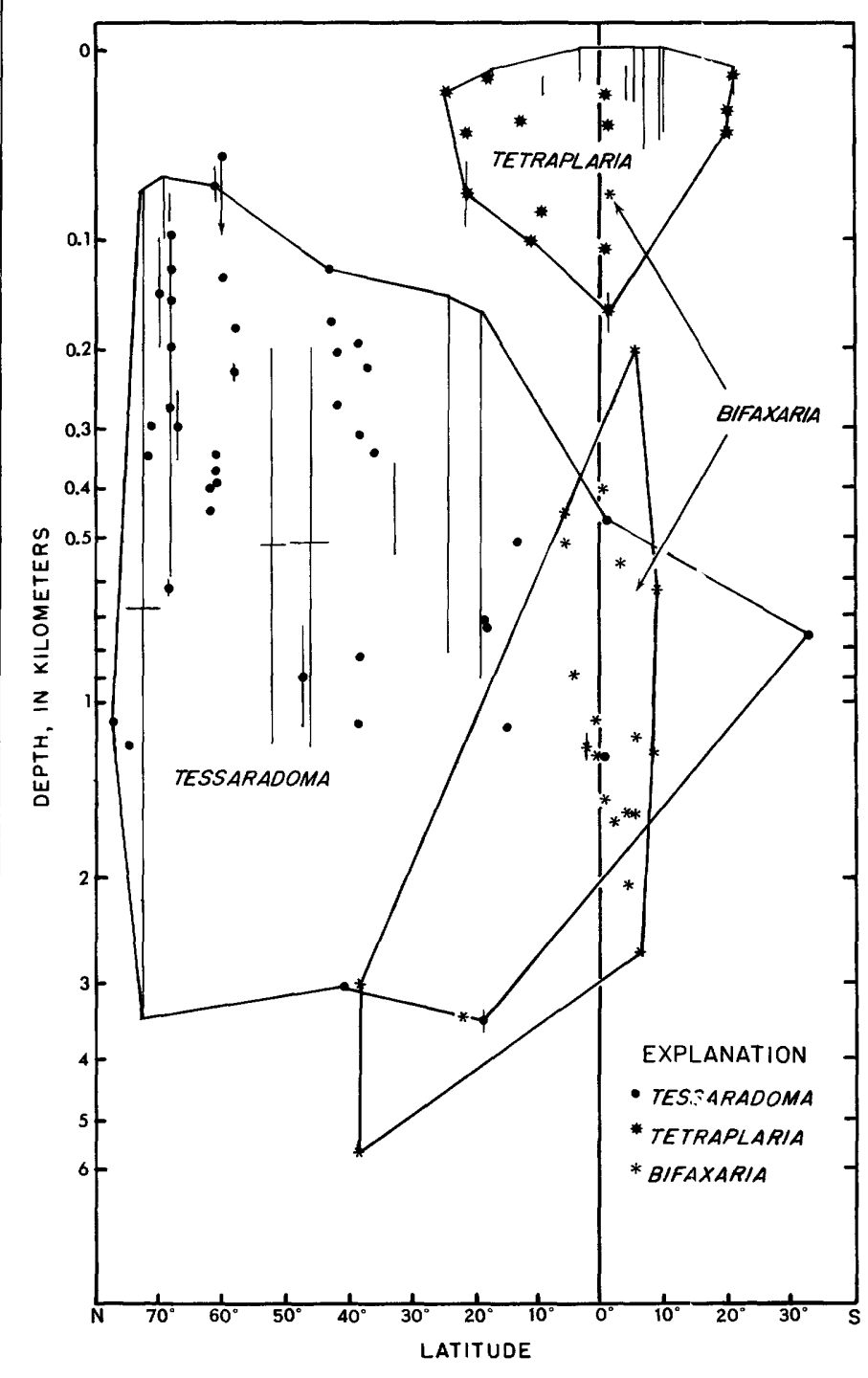

FIGURE 4.-Depth-latitude distribution of living species of three genera of cheilostome Bryozoa represented in upper Eocene beds on Eua, Tonga. Dots indicate single occurrences with specific depth-latitude data recorded; lines with median dots indicate single occurrences with only a rarge of depth or latitude recorded; lines alone indicate composite of occurrences with specific depth-latitude data recorded. The depth and latitude limits of each genus are shown $b^{-r}$ a polygon enclosing dots. Exclusion of the shallow-water oscurrence of Bifaxaria is explained in the text. Sources of data for Tetraplaria and Tessaradoma are the same as in figures 3 and 5; data for Bifaxaria are from Busk (1884), Canu and Bassler (1930), Harmer (1957), Hastings (1966), and Pourtalés (1874).

Bifaxaria is distinctly a deep-water genus, having only four of 23 reported occurrences at depths less than $500 \mathrm{~m}$. It occurs as deep as $3,477 \mathrm{~m}$ in the Atlantic and 5,719 $\mathrm{m}$ in the Pacific. Not all of the reported occurrences are at depths greater th an $200 \mathrm{~m}$, 
however, as suggested by Harmer (1957, p. 860 ; his Bifaxaria and Sclerodomus, see p. E11). Diplonotus costulatum Canu and Bassler is, as recognized by Harmer (1957), a bifaxariid, indeed a member of Bifaxaria as here constituted; it was reported from two stations in the Galapagos at 72 and $1,252 \mathrm{~m}$ by Canu and Bassler (1930). The deeper occurrence (Albatross sta. D. 3408) is represented by five large and four small pieces of colonies (paratypes, USNM 8503) retaining their covering membranes; these specimens were found with only two other cheilostome species, neither of which has been reported from other stations. Three small pieces, apparently broken from a single fragment (holotype, USNM 8502 ), all devoid of covering membranes, record the shallower occurrence (Albatross sta. D. 2813); 30 additional species, either well-known shallow-water species or species each represented by several specimens, were reported from this station. Additional bulk material from the 72-m sample failed to yield specimens of $B$. costulata. It is thus possible that the reported presence of this species at $72 \mathrm{~m}$ represents an accidental occurrence outside the living range of the genus, brought about, for example, by its transporta- tion on or in a nektonic organism.

The only direct indication of the thermal tolerance of Bifaxaria is the $4^{\circ} \mathrm{C}$ bottom temperature reported for the 1,252-m occurrence in the Galapagos (Albatross sta. D. 3408) ; the presence of covering membranes may indicate that the specimens were alive when collected. Occurrences deeper than $2000 \mathrm{~m}$ in both the Atlantic and Pacific could correspond to bottom temperatures of about $2^{\circ} \mathrm{C}$. By interpolation, the occurrences between 200 and $500 \mathrm{~m}$, all in the Philippine-Indonesian region, could be as warm as $15^{\circ} \mathrm{C}$ and are probably no colder than $10^{\circ} \mathrm{C}$. Thus, if the shallow-water Galapagos occurrence is ignored, the survival range for Bifaxaria appears tc be between about $2^{\circ} \mathrm{C}$ and a few degrees less than $15^{\circ}$ C.

If this temperature range is indeed the controlling factor for the depth of occurrence of Bifaxaria within its limited latitudinal distribution, it still does not explain the apparent absence of the genus from high latitudes, where it might be expected to occur in both shallow and deep water, or from the Indian Ocean. Other abiotic factors, geographic barriers, comretition with other species, or a combination of factors,

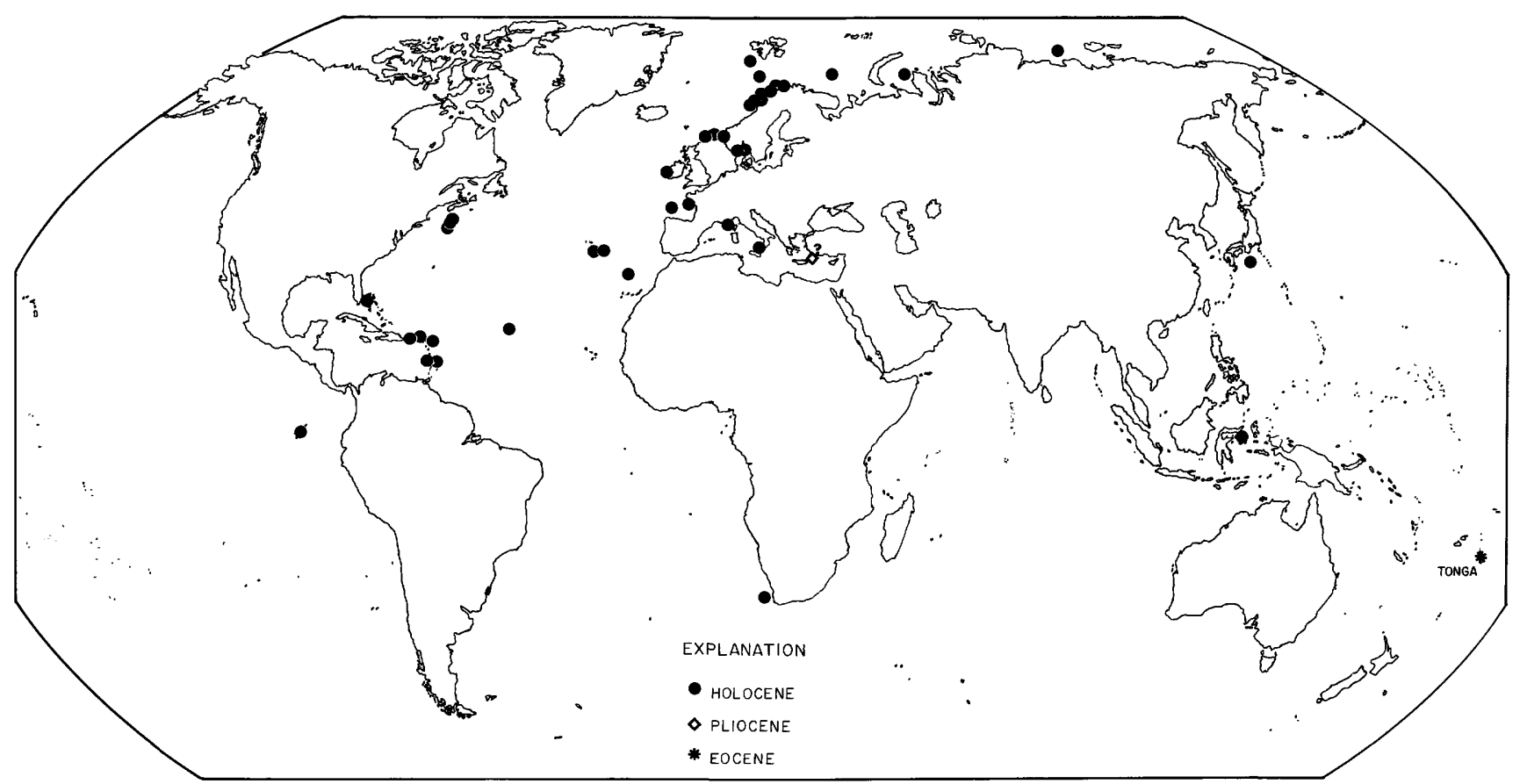

FIGURE 5.-Geographic and stratigraphic distribution of Tessaradoma. Sources of data are Burdon-Jones and TambsLyche (1960), Busk (1881, 1884), Calvet (1931), Canu and Bassler (1928a, 1930), LeDanois (1948), O'Donoghue (1924), Gautier (1962), Harmer (1957), Hincks (1880), Jullien and Calvet (1903), Kluge (1962), Lagaaij and Gautier (1965), Manzoni (1877), Nordgaard (1900, 1905, 1918, 1927), Norman (1894, 1909), Osburn (1940), Ryland
(1963), Sars (1851, 1862), Silén (1935), Smitt (1868, 1873 , and the following additional specimens in the collections of the National Museum of Natural History, Smithsonian Institution: T. boreale (Holocene, Albatross sta. D.2)62, $42^{\circ} 17^{\prime}$ N., $66^{\circ} 37^{\prime}$ W., $275 \mathrm{~m}$; Albatross sta. D. $2573,40^{\circ} 34^{\prime}$ N., $66^{\circ} 09^{\prime}$ W., $3181 \mathrm{~m}$; Albatross sta. D.2071, $41^{\circ} 56^{\prime}$ N., $65^{\circ} 49^{\prime}$ W., $207 \mathrm{~m}$; Caroline sta. $102,18^{\circ} 51^{\prime}$ N., 64 $34^{\circ} 33^{\prime}$ W., 164-915 m). 
might limit the geographic extent of Bifaxaria to only a part of the area within which it would encounter favorable temperatures.

\section{DISTRIBUTION OF TESSARADOMA}

The distribution of the three known living species of Tessaradoma (figs. 4,5 ) is consistent with a similar temperature range to that inferred for Bifaxaria, from about $2^{\circ} \mathrm{C}$ to about $13^{\circ} \mathrm{C}$. Tessaradoma, however, has a total depth range of 70 to $3,700 \mathrm{~m}$ and a latitudinal range of $77^{\circ} 05^{\prime} \mathrm{N}$. to $33^{\circ} 32^{\prime} \mathrm{S}$.

The greatest number of reports of this genus refer to the Arctic and Atlantic species T. boreale (Busk), whose latitudinal and depth ranges coincide with those of the genus. The two Pacific species, T. bipatens Harmer and T. striatum (Canu and Bassler), are known only from lat $30^{\circ} 45^{\prime} \mathrm{N}$. to $0^{\circ} 12^{\prime} \mathrm{N}$. and from depths of 469 to $1,252 \mathrm{~m}$.

In the Arctic and Norwegian regions, Tessaradoma occurs virtually throughout the whole range of depth. Equatorward, the deepest records remain about the same, $3,500 \mathrm{~m}$, but the shallowest occurrences show a gradual submergence from $70 \mathrm{~m}$ at lat $65^{\circ}-75^{\circ} \mathrm{N}$. to $120 \mathrm{~m}$ at lat $45^{\circ} \mathrm{N}$. to $150-160 \mathrm{~m}$ at lat $20^{\circ}-25^{\circ} \mathrm{N}$. to $450-500 \mathrm{~m}$ at lat $0^{\circ}-10^{\circ} \mathrm{N}$. The relation of the southern hemisphere outlier to this trend is not apparent.

The equatorward submergence of Tessaradoma in the North Atlantic is consistent with a cryophilic stenothermy having an upper limit for survival of about $12^{\circ} \mathrm{C}$. This limit must be slightly higher, however, for the genus occurs in the Mediterranean where bottom temperatures are never below about $13^{\circ} \mathrm{C}$, even at great depth (Furnestin, 1960).

Fossil occurrences of Tessaradoma have been reported from the Eocene of North Carolina and Alabama (Canu and Bassler, 1920), from the Miocene of Australia (MacGillivray, 1895), and from the Pliocene of Rhodes (Manzoni, 1877). The American species are not Tessaradoma but probably are referable to Semihaswellia; the Australian species belongs to Tubiporella; and the Rhodian species has not been found in subsequent study of the Pliocene fauna of that island (Pergens, 1887).

\section{TONGAN CHEILOSTOME FAUNAL ELEMENTS}

Association of Bifaxaria and Tessaradoma with Tetraplaria, Canda, and Triporula almost certainly indicates that the Tongan Eocene assemblage is a mixture of autochthonous and allochthonous elements. The habitats of these groups of species were tropical or subtropical but were separated bathymetrically by at least $85 \mathrm{~m}$ (fig. 4) and very probably by more than $150 \mathrm{~m}$, if the following assumptions are correct: (1) that the five apparently stenother- mal genera had approximately the same thermal requirements and bathymetric distributions in Eocene time as at present; and (2) either that Tessaradoma had the same gradient of submergence arproaching the equator from the south in the Eocene as it does approaching the equator from the north at present, or that its present minimum depth at $t \mathrm{l}$ ? equator characterized a broader latitudinal belt within a more widespread Eocene tropics. If, in additic $\eta$, the extreme bathymetric occurrences of Holocene species of Tetraplaria and Bifaxaria are accidental and outside the living ranges of Holocene species of the two genera, this reinforces interpretation of bathymetric disjunction of the Tongan faunas.

The autochthonous element is assumed to include all of the species represented in the assemblage by significant numbers of specimens plus any others inferred to have the same thermal significance. Each of the first three species listed in table 1 is represented by at least three times as many specimens as are any of the other species. The three abundant species plus two others having the same thermal significance make up almost 85 percent of the specimens in the assemblage.

Of the well-represented species, one is a Bifaxaria, and the other two apparently belong to eurythermal genera, Spiroporina and Reteporellina. T' is species of Spiroporina is morphologically comparable to an apparently cryophilic living species, $S$. brevitubulata Harmer, which occurs in the Philippine-Indonesian region at depths of 204 to $1,633 \mathrm{~m}$ (Harmer, 1957). Bifaxaria diaphyota and Spiroporina kondoi then indicate the cool- and deep-water character of the autochthonous element, and two other cryophilic species can be inferred to be part of this element, even though they are represented by far fewer specimens (table 1) ; these species belong to Bifaxaria and Tessaradoma. The autochthonous group of species, then, lived at a depth of probably more than $200 \mathrm{~m}$ and perhaps more than $1,000 \mathrm{~m}$.

The allochthonous faunal element, as interpreted here, includes those species except Tessaradoma bifax which occur in minor frequencies (1-5; table 1$)$ in the assemblage. These 13 species make up slightly more than 15 percent of the specimens.

Six species are inferred to have been thermophilic and restricted to shallow water, probably less than $100 \mathrm{~m}$ deep. These include two species of Tetraplaria, a Canda, a Triporula, and apparently trermophilic species of the eurythermal genera Spiroporina and Beania. The species of Spiroporina is comparable morphologically to S. longicollis (Canu and Bassler), which occurs in the Philippine-Indonesian region at 
depths no greater than $73 \mathrm{~m}$ (Harmer, 1957). The Tongan species of Beania has its nearest living counterpart in the Indonesian $B$. asymmetrica Harmer, known from depths no greater than $40 \mathrm{~m}$ (Harmer, 1926). Six of the remaining species belong probably to eurythermal genera, and none of them is closely comparable with stenothermal living species. They are included tentatively in the allochthonous element because of their low frequencies of occurrence and the lack of evidence that they were restricted to cool water. The last species, Tubitrabecularia clypeata, is assigned to the allochthonous element even more tentatively, for the genus Tubitrabecularia is extinct. The probably closely related, living genus Siphonicytara is known from depths of 469 to $1,901 \mathrm{~m}$ in Indonesia (Harmer, 1957), but species of Tubitrabecularia occur in the Australian Tertiary with distinctly shallow-water genera.

The autochthonous element includes only typically benthic species, as indicated by growth forms that require attachment to a firm substrate. The allochthonous fauna, on the other hand, could have been benthic, and therefore transported laterally as well as vertically to a deeper burial site, or epiplanktonic, and therefore moved essentially only vertically to the sea floor. This faunal element includes a variety of growth forms, some of which, as in Beania diademata, both species of Tetraplaria, and Cellaria cucullata, are adapted to movable substrates including floating objects. If they consistently followed this mode of life, however, these species could have highly eurybathic distributions. Furthermore, Tongan specimens of Triporula and Chiastosella(?) are clearly adherent to nonbouyant substrates. Thus, part if not all of the allochthonous group of species was probably transported to the site of burial from a shallower bottom habitat.

Some, but by no means all, of the Holocene occurrences of Canda, Tetraplaria, and Triporula have been reported to be on coral, coral sand, or Lithothamnium associated with reefs. Other cheilostome genera commonly associated with Holocene reefs include Celleporaria, Nellia, Poricellaria, Steganoporel$l a$, and Thalamoporella, all known to occur in rocks of Eocene age in Europe and North America, as well as several genera not known from the Eocene. All of these genera have been reported from numerous Holocene localities in the Indo-Pacific. The likelihood of a reefal origin for the allochthonous Tongan element thus is not strong.

Four species considered to belong to the allochthonous, shallow-water Tongan faunal element-Beania diademata, Canda fossilis, Menipea innocua, and Cel- laria cucullata-are members of families (Bicellariellidae, Scrupocellariidae, and Cellariidae) regarded as characteristic of the deep sea (Schopf, 1969 , p. 470). Each family, however, includes one genus or more that occurs eury- or stenobathically in shallow water.

\section{MORPHOLOGY OF DEEP-WATER SPECIES}

In contrast to the wide variety of colony fcrms displayed by the allochthonous component of the Tongan Eocene assemblage, the inferred deep-water species appear to have had more uniform colonies and therefore to represent more restricted adaptations (table 1). They belong to three ascophoran families, Bifaxariidae, Spiroporinidae, and Sertellidae. T're is no positive evidence that anascans were represented in the autochthonous faunal element, and the least calcified forms, Beania diademata and Canda fossilis, were apparently distinctly shallow-water allochthones in this assemblage. All the Tongan deep-water species have zooecial frontal shields susceptible of continued calcareous accretion throughout ontoceny. This property characterizes ascophorans having both known modes of frontal shield development (see Boardman and Cheetham, 1969, p. 222).

The growth forms of colonies of these deep-water species are not observable directly because all specimens are small zoarial fragments, the largest being less than a centimeter long. Some of these fragments preserve stubs of distalward branches, and from these and from changes in morphology associated with ontogenetic thickening of zooecial frontal shields, the form and size of colonies can be estimated. Within each zoarial fragment, frontal shields of proximal zooecia are slightly thicker than those of distal zooecia; other morphologic features, such as frontal pores, avicularia, and secondary orifices, may show correlated ontogenetic differences. In the three species having zooecia arranged biserially back to back (Bifaxaria bryani, B. diaphyota, and Tessaradoma bifax), the frontal shields of the two series of zooecia meet on the lateral surfaces of the $k$ ranches, and zooecia placed more proximally on a fragment are slightly wider, viewed frontally, than those distal to them (see pl. 3, figs. 1, 2; pl. 4, figs. 4, 5; pl. 5, figs. 4, 5). B. diaphyota is sufficiently abundant that zoarial fragments having zooecia of differing widths form a series with overlapping ranges. Jven though the differences within a fragment are berely perceptible, the mean widths in all fragments having zooecia with thicker frontal shields are significently greater than all those having thinner shields (see measurements, p. E13). A colony of $B$. diaphyota may 
have consisted of many such fragments arranged in a distalward branching form, with the base diameter of the stem almost twice as thick as the diameter of the branches near their growing tips. By analogy, it can be inferred that the two rarer biserial species had the same general growth form.

In Spiroporina kondoi, the zooecia are in four series opening radially around the branch. Distalward branching and ontogenetic zooecial changes suggest that otherwise the colonies were similar to the biserial ones. In Reteporellina? sp., the two- to fourserially arranged zooecia all open on one zoarial surface. On the opposite sides of the fragments, extrazooecial calcareous material appears to follow the same ontogenetic gradient of thickening as do the zooecial frontal shields.

All these deep-water species appear to have had rigidly erect, nonfenestrate colonies with subcylindrical or slightly compressed branches (vinculariiform and eschariform; table 1) in which outer skeletal walls continuously thickened throughout life. The proximal ends of these colonies seem missing in the material at hand, but, in the absence of skeletal evidence of attachments for noncalcified rootlets or tendrils, it is assumed that colonies were attached directly to the substrate by small encrusting bases, as shown in the living deep-sea species Tessaradoma striatum by Canu and Bassler (1930, pl. 10, fig. 1). This morphology is similar to that of shelf cheilostomes having vinculariiform and eschariform colonies, and it appears to represent a similar adaptation for growth approximately perpendicular to the substrate, increasing exposure to the water column. This mode of growth seems advantageous in filter feeding.

A survey of living faunas has suggested that deepsea cheilostomes are generally characterized by bushlike commonly lightly calcified colonies attached to the substrate by noncalcified rootlets and tendrils which may hold them in a prostrate rather than an erect position (Schopf, 1968, p. 154; 1969, p. 470). This morphology was thought to be an adaptation for growth on the finely particulate substrates in the deep sea and possibly for detritus-feeding from the fine sediment (Schopf, 1969, p. 469-471). This characterization was based on genera in the anascan families Farciminariidae, Scrupocellariidae, Bicellariellidae, and Cellariidae (especially the genus Euginoma) and in one ascophoran family, the Bifaxariidae. The heavily calcified colonies of all the Tongan Eocene species inferred to live in deep water suggest that deep-sea cheilostomes may have adaptations comparable with those of shallow-water forms, and similar bifaxariids, spiroporinids, and sertellids are, of course, known in the living faunas (see Harmer, 1957).

\section{SYSTEMATIC PALEONTOLOGY}

\author{
Suborder ANASCA Levinsen, 1909 \\ Family CHAPERIIDAE Jullien, 1888 \\ Genus PATSYELLA Brown, 1948 (?) \\ Patsyella? sp. \\ Plate 1, figure 3
}

A single zoarial fragment from sample 1 may belong to Patsyella, a genus known from Oligocene to Holocene in New Zealand (Brown, 1952, p. 118, 122).

The colony was apparently erect, the zooecia arranged in four alternating series, one on each face. There is no evidence of branching.

The zooecia are quadrate, their distcl margins convexly rounded, their proximal margins concavely rounded. Deep grooves separate laterally adjacent zooecia. The narrow, smooth, rounded mural rim lies at the interzooecial boundaries, witl sut intervening gymnocyst. The concave, imperforate, finely tuberculate cryptocyst slopes gently away from the proximal and lateral mural rim to the broadly ovate opesia which occupies the distal half of the frontal surface of the zooecium. On some zooecia, a pair of ill-defined ridges diverge proximally from the lateral mural rim and extend to the proximal end of the cryptocyst.

The opesia is bordered on its proximal and lateral margins by a narrow, smooth rim turnod slightly under. Below the opesia, an occlusor-lamina runs from the distal wall to each lateral wall, forming small distolateral pouches opening frortally. The occlusor-laminae are more strongly developed in this specimen than is typical of Patsyella, though their development is considerably less than in Chaperia.

Entozooecial ovicells are present on several zooecia placed around the zoarial fragment withort apparent pattern. The ovicell is immersed in the distal zooecium, just visible frontally as a small swelling on the cryptocyst. The opesiae of the ovicelled zooecia are slightly larger than those of nonovicelled zooecia.

Oral spines and avicularia are not present on the specimen.

\section{Family CELLARIIDAE Hincks, 1880 Genus CELLARIA Ellis and Solander, 1786 Cellaria cucullata MacGillivray Plate 1, figure 4}

Cellaria cucullata MacGillivray, 1895, Royal Soc. Victoria Trans., v. 4, p. 31, pl. 22, fig. 15.

Brown, 1958, Geol. Survey Victoria Mem., no. 20, p. 47, figs. 20, 21. 
A single internode fragment from sample 1 belongs to Cellaria cucullata. The preserved distal end of the internode shows three large, subcircular openings alternating with three small, triangular ones; the proximal end is broken. The uniformly hexagonal zooecia are arranged in six alternating series, in three of which, corresponding to the smaller distal openings, the zooecia terminate with the internode. The rounded-quadrate opesia lies at about zooecial midlength, lacks denticles, and is surrounded by a narrow, slightly raised rim from which the cryptocyst falls away more steeply distally to form, in some zooecia, the ovate hollow characteristic of the species (Brown, 1958, p. 47). Ovicells and avicularia were not found.

C. cucullata has been reported from beds of late Eocene age in Victoria, Australia.

\section{Family BICELLARIELLIDAE Levinsen, 1909 Genus BEANIA Johnston, 1840 \\ Beania diademata, n. sp. \\ Plate 2, figure 3}

Zoarium unilaminate, apparently loosely encrusting, multiserial, with small, ovate fenestrae, visible only in basal view, between zooecia. Connecting tubes stout, joining each zooecium to six neighbors.

Zooecia very heavily calcified for genus, cucullate; proximal portion short, stout, forming part of proximal connecting tube; distal portion raised obliquely to overhang, but not rest upon, succeeding zooecium, hiding its proximal end from frontal view. Mural rim thick, rounded, finely tuberculate, slightly constricted in oral region, more constricted on one side which supports a large protuberant tubular collar probably marking attachment of avicularium. Spine bases distributed in four series: (1) bases of seven to nine small closely spaced spines placed along each lateral mural rim, proximal to oral constriction, paired bilaterally except for most distal spine base opposite apparent avicularium base, all projecting frontally; (2) bases of two small oral spines placed bilaterally on distolateral mural rim, projecting frontally; (3) bases of nine small spines placed in a symmetrical distolateral crown, one spine base occupying a medial position, around distal third of zooecium, just outside the spine bases on mural rim and more widely spaced, projecting distofrontally and frontolaterally; and (4) bases of five to eight larger spines irregularly distributed over basal surface. Opesia elongate, elliptical, occupying almost all of zooecial surface in frontal view.

Ovicells not observed.

Zooecial dimensions (in $\mathrm{dk} \mu$ ) measured in frontal view on holotype are as follows (mean and stantard deviation given to two decimal places for purposas of calculation only) :

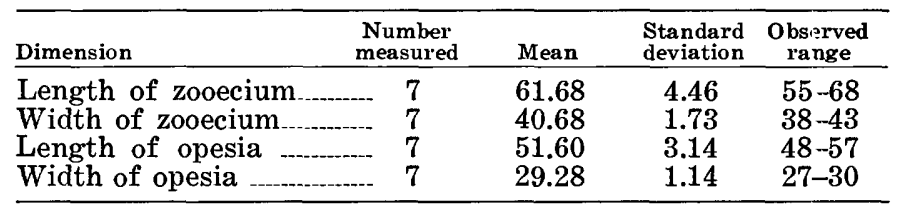

Holotype, USNM 169234, sample 2. Upper Eosene, about one-quarter mile north of Vaingana, Eua, Tonga, at altitude 400 feet.

Beania diademata resembles the living species $B$. asymmetrica Harmer, 1957, in the placement of its (probable) avicularium and in the size of its zoarial fenestrae, the connection of its zooecia by six tubes, and the distribution of its basal spines. $B$. asymmetrica has no spines on the mural rim or in a clistolateral crown, however. The number of spines on the frontal side of the zooecium in $B$. diademata is similar to that in the living species $B$. hirtissima (Heller, 1867), but the spines are distributed differently. Thus $B$. diademata, though represented by the single specimen, is highly distinctive.

Two fossil occurrences of Beania have been reported previously. MacGillivray (1895, p. 27) identified a poorly preserved early Miocene specimen from Australia, having only its basal surface observable, with $B$. spinigera (MacGillivray, 1880), a living Australian species, from which $B$. diademata differs in its smaller fenestrae and more numerous, differently distributed spines. The second fossil species, B. bermudezi Lagaaij (1968, p. 349, pl. 11, figs. 11-14), described from middle and upper Eocene beds in Cuba, differs from $B$. diademata in he.ving only four connecting tubes for each zooecium, differently arranged spines, and ovicells.

\section{Family SCRUPOCELLARIIDAE Levinsen, 1909 Genus CANDA Lamouroux, 1816 \\ Canda fossilis Waters \\ Plate 1, figures 1, 2}

Canda fossilis Waters, 1881, Geol. Soc. London Quart. Jour., v. 37 , p. 322 , pl. 16, figs. 51,52 .

Waters, 1882, Geol. Soc. London Quart. Jour., v. 38, r. 261.

Waters, 1883, Geol. Soc. London Quart. Jour., v. 39, p. 433

MacGillivray, 1895, Royal Soc. Victoria Trans., v. 4, p. 25, pl. 3, figs. 12-14.

Brown, 1958, Geol. Survey Victoria Mem., no. 20, p. 50.

Four zoarial fragments, all from sample 2, belong to Canda fossilis, described from lower Miocene beds (Balcombian Stage), in Victoria, Australia.

The growth form of these colonies apparently was unjointed, for one of them (pl. 1, fig. 2) exhibits a 
dichotomy with the zooecia continuously calcified from stem to both branches. The arrangement of zooecia in these biserial specimens is typical of Canda (see Harmer, 1926, p. 385) and conforms at the dichotomy to Harmer's (1923, p. 328) type 17 bifurcation. The inner zooecia at the proximal ends of the branches (denoted $\mathrm{F}$ and $\mathrm{G}$ by Harmer) meet in their proximal segments above the axillary zooecium (denoted $\mathrm{E}$ ). Both zooecia $\mathrm{F}$ and $\mathrm{G}$ are provided with basal vibracula, as in living species of Canda.

The zooecia are slightly curved outward in frontal view; have a pair of symmetrically placed, small distal spine bases; and support a prominent scutum attachment just distal to the middle of their inner margin. The scutum attachment seems to correspond to the structure in the Australian specimens interpreted by Waters $(1881$, p. 322$)$ as an avicularium or spine and by MacGillivray $(1895$, p. 26) as a sessile avicularium; it lies distinctly on the inner frontal surface of the zooecium, rather than on the lateral slope that forms the keel of the branch and on which avicularia commonly occur in living species of Canda (see Harmer, 1926, p. 384). The zooecial opesia is V-shaped as is characteristic of $C$. fossilis. In basal view, a markedly zigzag suture separates the zooecia.

Frontal avicularia occur only on the branched specimen on zooecia considerably proximal to the bifurcation, rather than at the bifurcation as is typical of some species of Canda (see Harmer, 1926, p. 384). The avicularia lie on the inner margins of the zooecia, just proximal to the scutum attachment. Their rostra, though broken, appear to be directed laterally toward the opesiae of adjacent zooecia.

The vibracula lie on the interzooecial sutures on the basal sides of the branches; their articular ends are just visible in frontal view. The rostral channels curve around prominent rootlet foramina.

Ovicells were not found in the Tongan material.

Genus MENIPEA Lamouroux, 1812

Menipea innocua Waters

Plate 2, figure 2

Menipea innocua Waters, 1882, Geol. Soc. London Quart. Jour. v. 38 , p. 261 , pl. 9 , fig. 24 .

A single zoarial fragment from sample 2 seems identifiable with Menipea innocua described from the lower Miocene (Balcombian Stage) of Victoria, Australia.

The colony apparently was not jointed, but dichotomously branched. The zooecia are in biserial, alternating rows. Their arrangement at the bifurca- tions appears to be consistent with Harmer's (1923, p. 328) type 17 , with the inner zooecia of the branches meeting over the axillary zooecium. The outlines of zooecia of all rows are visible on the otherwise smooth basal surface of the fragment. The arrangement of zooecia, especially as shown on the basal surface, differs markedly from that in the Australian Miocene species M. elongata (Canu and Bassler, 1935, p. 14, pl. 3, figs. 6, 7) in which the morphology of the zooecia is similar, and similar to that in the living Philippines species $M$. crassa (Canu and Bassler, 1929, p. 221, pl. 10, figs. 10-13).

The zooecia of the Tongan specimen differ from those of $M$. crassa in having more sharply raised mural rims enclosing more steeply plunging cryptocysts. The elongate gymnocysts of about half the zooecia support, just proximal to their mural rims, adventitious avicularia with pointed rostra directed laterally toward the outer margins of the zooecia. The avicularia are longer than those of $M$. crassa and, on the proximal sides of their chambers, are each provided with a foramen, possibly for attachment of a rootlet. The form and distribution of the adventitious avicularia differ from those in two Australian Eocene-Oligocene species, $M$. retrorsa and $M$. biaviculata, described by Maplestone (1900, p. 164, 165, pl. 17, figs. 8, 10).

\section{Family CRIBRILINIDAE Hincks, 188 ? Genus FIGULARIA Jullien, 1886 (?) \\ Figularia? sp. \\ Plate 2, figure 1}

One zoarial fragment, from sample 2, may belong to Figularia. It is similar in its apparent growth form and zooecial morphology to $F$. kenleyi Brown (1958), p. 53, fig. 31), a species described from the upper Eocene of Victoria, Australia, knt differs from all known species of Figularia in its ovicells and avicularia.

The colony was apparently erect, with the zooecia arranged in four alternating series, one on each face. There is no evidence of branching.

The elongate-claviform zooecia have long, smooth proximal gymnocysts, extending as much as onethird the zooecial length and continuing as narrow strips along the lateral margins nearly to the distal end. Around the inner margins of the prcximal and lateral gymnocyst are distributed 20 to 23 bases of costae or spines. On one zooecium at least the proximal two pairs of bases apparently wer? parts of costae, for the most proximal pair reaches the midline where their inner ends are fused, and the next pair approaches the midline with their inner ends 
fused to those of the proximal pair. A single slitlike lacuna is left between adjacent costae. The frontal surfaces of the costae are smooth and imperforate. The distal pair of bases on the nonovicelled zooecia are larger and have larger lumina than the more proximal bases and thus may be parts of oral spines rather than costae. $F$. kenleyi has similar frontal structure, but has fewer costae and no oral spines.

Just proximal to the remnants of its costal shield, each zooecium has an adventitious avicularium placed laterally on the proximal gymnocyst. The mandibular palate is elevated and inclined distolaterally, and the rostrum is directed medially, frontally, and slightly distally. Pivotal structures were not observed. Avicularia are lacking in $F$. kenleyi.

Broken ovicells are present on two zooecia. Unlike those of $F$. kenleyi, the ovicells are entozooecial, immersed in the distal zooecia, and visible frontally only as small swellings in their proximal gymnocysts. The larger pair of spine (?) bases is lacking on the ovicelled zooecia.

Suborder ASCOPHORA Levinsen, 1909 Family EXECHONELLIDAE Harmer, 1957 Genus TRIPORULA Canu and Bassler, 1927

Triporula aff. T. biarmata (Waters)

Plate 2, figure 4

One poorly preserved zoarial fragment, encrusting a worn piece of decapod crustacean from sample 2, belongs to Triporula. Like T. biarmata (Waters, 1882 , p. 268 , pl. 8, fig. 18), a species living in Australian waters and occurring as fossils in beds of early Miocene age in Australia and in beds of Oligocene-Pliocene age in New Zealand (Brown, 1952, p. 358), this specimen displays numerous small frontal pores and small, paired lateral-oral avicularia in addition to a median distal avicularium. The lateraloral avicularia, however, are directed medially, rather than distally as in T. biarmata and most other species of this genus, and their rostra commonly meet on the proximal lip of the orifice. Also, the zooecia of the Tongan specimen are less than half as large as those of T. biarmata (see Brown, 1952, p. 357; Cook, 1967, p. 341). T. verrucosa (Canu and Bassler, 1920), a Paleocene species from Georgia, has small zooecia, but its lateral-oral avicularia are placed more distally relative to the orifice than in the Tongan specimen and are directed distally.

The frontal pores of the Tongan specimen appear not to be stellate, but their original shape may not be preserved. Each pore, even in zooecia apparently near the growing margin of the colony, is surrounded by a distinct tubular collar. The three avicularia on each zooecium are in series with the outer row of pores, and, on zooecia apparently at the growing margin, this row of pores lies frontally away from the dietellae from which they are separated by an interval of vertical wall, as noted by Cook (1967, p. 342) in living species of Triporula.

\section{Family BIFAXARIIDAE Busk, 1884}

Harmer (1957, p. 859) considered this family and and the family Sclerodomidae Levinsen, 1909, synonymous; so he combined them under the nam? $\mathrm{Bi}$ faxariidae. As discussed below, Harmer's (1957, p. 866) concept of Sclerodomus Levinsen, 1909, appears to be inconsistent with the characters of its type species, Bifaxaria denticulata Busk, 1884, which is morphologically unlike the other species included by Busk in Bifaxaria, and those included in Urceolipora MacGillivray, 1881. Also unlike kifaxariids, Sclerodomus sensu stricto and other gevera, such as Cellarinella Waters, 1904, that have been assigned to the Sclerodomidae, have distributions including the Antarctic and subantarctic regions. Bifaxariids and sclerodomids should probablr be maintained as separate families.

\section{Genus BIFAXARIA Busk, 1884}

The Tongan specimens described below as Eifaxaria bryani, n. sp., and $B$. diaphyota, n. sp., appear to be the first known fossil bifaxariids, and their affinities seem to be with the living species $B$. corrugata Busk, 1884, and B. papillata Busk, 1884. Both these living species were referred by Harmer (1957, p. 867-868) to Sclerodomus, but there are reasons, some of which were mentioned by Hastings (1966, p. 59), to question this assignment.

As constituted by Busk (1884, p. 79), Bifaxaria included a heterogeneous assemblage of eight species; the heterogeneity was recognized by Waters (1888, p. 15) and Levinsen $(1909$, p. 302-304), who established Sclerodomus for $B$. denticulata, the only species included in Bifaxaria having more than two series of zooids, sinuate secondary orifices, and median suboral avicularia equipped with complete crossbars. Harmer $(1957$, p. 861, 866) considered all the originally included species in which the colonie are not jointed, except $B$. abyssicola Busk, 1884, to belong in Sclerodomus. He implied that the development of secondary avicularia covering earlier frontal structures also distinguishes Sclerodomus from $\mathrm{Bi}$ faxaria, but in $B$. corrugata secondary avicularia are lacking (Hastings, 1966, p. 60) ; the specimen on which Busk $(1884$, p. 80 ) noted their presenco belongs to $B$. papillata (Hastings, 1966, p. 59). The 
concept of Sclerodomus proposed by Harmer thus is too broad and probably should not include the biserial species. If the nonjointed species here considered to belong to Bifaxaria were separated generically from the jointed ones, a new genus would be required for them.

In both the Tongan species described below, the bases of the branches, where they join the colony stem, consist of two zooecia in opposition, back to back. This arrangement appears not to differ from that in the bipartite bases rami shown by jointed species of Bifaxaria (Harmer, 1957, p. 861) and suggests that there is little structural difference between the jointed and the unjointed biserial bifaxariids.

$$
\begin{gathered}
\text { Bifaxaria bryani, n. sp. } \\
\text { Plate 4, figures } 4,5
\end{gathered}
$$

Zoarium rigidly erect, apparently not anastomosing, pinnately branched; branches given off singly, their distribution suggesting arrangement in alternating pairs from main stem. Stem and branches subcylindrical, consisting of two alternating series of zooids arranged back to back; at base of branch, first pair of zooecia oppose rather than alternate. Branches arise from frontal sides of stem zooecia, all zooecia thus open in plane of branching. Zoarial fragments apparently from proximal parts of colonies have diameters almost twice those apparently from distal parts. Basal attachments not found.

Zooecia with transversely hexagonal frontal surfaces, lateral portions of which wrap around lateral surfaces of branch so that in lateral view, adjacent zooecia are separated by narrow, slightly raised, markedly zigzag ridge. Viewed frontally, zooecia appear rounded rectangular, their width about fivesixths length in distal fragments and as much as $11 / 2$ times length in proximal fragments. Frontal shield inflated, smooth except for narrow, discontinuous, irregularly sinuous, slightly raised submedian ridge, on each side of which are six to eight approximately alined longitudinal rows of oval to slitlike pores; on distal zooecia, frontal shields are thinner with submedian ridge more regularly positioned than on proximal zooecia. Secondary orifice terminal on frontal surface, slightly wider than long, rounded trapezoidal with the longest side distal; distal margin broadly arcuate; proximal margin almost straight-sided laterally, strongly indented medially by a prominent, pointed mucro which usually continues the frontal submedian ridge. Secondary orifices of presumed ovicelled zooecia not apparently different from those of nonovicelled zooecia.
Avicularia adventitious, of two positions: lateraloral and lateral. Lateral-oral avicularia small, paired, paralleling margins of secondary orifice, with rostra directed distolaterally. Lateral avicularia larger, single or paired, rarely occurring in greater numbers on zooecia at base of branch or distal to ovicell, lacking on distal zooecia except at points of branching; placed on lateral portions of zooecial frontal shield, near zigzag interzooecial boundary, commonly in an irregularly longitudinal line; rostra oriented distally, proximally, laterally, or medially, but rarely obliquely. Rostra of both latersl and lateral-oral avicularia broadly spatulate; pivotal condyles are broad, rounded knobs at about midlength on palatal surface.

Ovicells, if present, completely immersed in distal zooecia, apparent externally only as swellings in their frontal shields.

Zooecial dimensions (in $\mathrm{dk} \mu$ ) measured in frontal view on six zoarial fragments (holotype and five paratypes) are summarized as follows (mean and standard deviation given to two decimal places for

\begin{tabular}{|c|c|c|c|}
\hline $\begin{array}{c}\text { Number } \\
\text { measured }\end{array}$ & Mean & $\begin{array}{l}\text { Standard } \\
\text { deviaticn }\end{array}$ & $\begin{array}{c}\text { Observed } \\
\text { range }\end{array}$ \\
\hline \multicolumn{4}{|l|}{ Length of zooecium: } \\
\hline Distal zooecia & 66.19 & 3.50 & $61-71$ \\
\hline Proximal zooecia & 71.27 & 9.59 & $57-91$ \\
\hline \multicolumn{4}{|l|}{ Width of zooecium: } \\
\hline Distal zooecia & 56.78 & 1.56 & $55-59$ \\
\hline Proximal zooecia & 99.90 & 14.71 & $77-122$ \\
\hline Length of orifice & & & \\
\hline (secondary) & 18.10 & 1.81 & $14-21$ \\
\hline $\begin{array}{l}\text { Width of orifice } \\
\text { (secondary) }\end{array}$ & ת 10 & 261 & 17-25 \\
\hline Length of avicularium: & 20.10 & 2.61 & $17-20$ \\
\hline Lateral-oral 18 & 10.41 & 1.80 & $7-15$ \\
\hline Lateral 16 & 16.38 & 4.04 & $8-22$ \\
\hline
\end{tabular}
purposes of calculation only) :

Tested by Student's $t$, the difference in mean lengths of distal and proximal zooecia is not significant $(0.05$ level $)$, and the difference in mean widths of distal and proximal zooecia is highly significant (0.01 level). The difference in mean lengths of lateral-oral and lateral avicularia is also lighly significant.

Holotype, USNM 169241, paratype, USNM 169242 , and 2 paratypes, USNM 169243, sample 2 . Two paratypes, USNM 169244, sample 1. Upper Eocene, about one-quarter mile north of Vaingana, Eua, Tonga, at altitude 400 feet.

Bifaxaria bryani is most similar to the living species B. corrugata Busk, from which it differs in the frontal shield being smooth rather than longitudinally ridged between the rows of pores, the secondary orifice having a prominent mucro, and the lateral portions of the frontal shield being equipped 
with avicularia in the more heavily calcified proximal zooecia. The presence of lateral avicularia in $B$. bryani links it with the living species $B$. papillata Busk, B. gigantea (Harmer), and B. rugata (Harmer) and with the Tongan Eocene $B$. diaphyota, $\mathrm{n}$. sp., described below. Unlike the living species, the Tongan species appear to have the lateral avicularia no larger distal to ovicells and at the points of branching than at other locations.

As. in other species of Bifaxaria, the zooids in the proximal parts of colonies of $B$. bryani apparently differed markedly from those in the distal parts, chiefly as the result of ontogenetic changes in the frontal shield. The most conspicuous change (compare pl. 4 , figs. 4 and 5) is the increase in shield thickness, resulting in doubling the diameter of the branch. As in B. corrugata (see Hastings, 1966, p. 59-60), thickening took place without the development of frontal avicularia, except at the lateral extremities of the shield in $B$. bryani, so that the submedian ridge, the oral mucro, and the longitudinal rows of pores continue, for the most part, into the later ontogenetic stages with little change in form. Unlike B. corrugata, however, B. bryani shows no tendency to develop longitudinal ridges between pore rows and therefore lacks, at all stages, the corrugated appearance of the living species. The pattern of pore rows in $B$. bryani is interrupted around lateral avicularia on the more heavily calcified zooecia and on zooecia at the base of a branch; the pores around these avicularia appear to be radially arranged.

\section{Bifaxaria diaphyota, n. sp. Plate 3, figures 1-7}

Zoarium rigidly erect, apparently not anastomosing, pinnately branched; branches given off in opposing pairs. Stem and branches subcylindrical, consisting of two alternating series of zooecia arranged back to back; at base of branch, first pair of zooecia oppose rather than alternate. Branches arise from frontal sides of stem zooecia, all zooecia thus opening in plane of branching. Zoarial fragments apparently from proximal parts of colonies have diameters up to twice as large as those from distal parts. Basal attachments not found.

Zooecia with trapezoidal frontal surfaces, the widest margin at proximal end; lateral portions wrap around lateral surfaces of branch, so that, in lateral view, adjacent zooecia are separated by deep, moderately zigzag groove. Viewed frontally, zooecia appear almost triangular, with rounded apex at distal end; zooecial width varies from subequal in length in distal fragments to nearly twice length in proximal fragments. Frontal shield inflated, incised medially with a deep longitudinal groove, on each side of which are few scattered large rores; frontal surface finely pitted, the pits in places alined in striate patterns; shields appear thick even on distal zooecia, thicker on proximal ones; on heavily calcified zooecia, buildup of avicularia imparts a papillose surface texture within which interzosecial boundaries become obscure. Secondary orifice terminal on frontal surface, strongly inclined distally, roughly semicircular with broadly rounded distal margin, nearly straight proximal lip slightly cleft by median frontal groove.

Avicularia adventitious, of two positions; lateraloral and frontal. Lateral-oral avicularia (not ol servable on most zooecia because of poor preserve.tion) very small, paired, placed at distolateral corners of secondary orifice, facing slightly into peristome, directed distomedially. Frontal avicularia numerous, variable in position on surface of frontal shield, tending to bilaterally symmetrical placement; distal zooecia have two or three pairs of avicularia placed laterally, near zigzag interzooecial grooves; more proximal zooecia have three to five additional pairs placed more medially, usually including a pair placed on either side of median frontal groove in vicinity of secondary orifice; heavily calcified, most prcximal zooecia in material have many additional avicularia scattered over both median and lateral portions of frontal surface. Rostra narrowly to broadly spatulate, directed in apparently any direction. Pivotal condyles indistinct.

Ovicells not apparent in material studied.

Zooecial dimensions (in $\mathrm{dk} \mu$ ) measured in frontal view on eight zoarial fragments (holotype and paratypes 169246-169252) are summarized as follows (mean and standard deviation given to two decimal places for purposes of calculation only):

\begin{tabular}{|c|c|c|c|c|}
\hline Dimension & $\begin{array}{c}\text { Number } \\
\text { measured }\end{array}$ & Mean & $\begin{array}{l}\text { Standard } \\
\text { deviation }\end{array}$ & $\begin{array}{c}\text { Observed } \\
\text { range }\end{array}$ \\
\hline \multicolumn{5}{|l|}{ Length of zooecium: } \\
\hline Distal zooecia & 1 & (1) & (1) & en \\
\hline Intermediate zooecia & 3 & 59.08 & (1) & $59-60$ \\
\hline Proximal zooecia & 25 & 65.35 & 10.70 & $51-97$ \\
\hline \multicolumn{5}{|l|}{ Width of zooecium: } \\
\hline Distal zooecia & 2 & 63.84 & (1) & $60-67$ \\
\hline Intermediate zooecia & 3 & 70.84 & (1) & $66-78$ \\
\hline Proximal zooecia & 25 & 89.82 & 8.84 & $76-113$ \\
\hline \multicolumn{5}{|l|}{ Length of orifice } \\
\hline (secondary) - & 31 & 19.46 & 3.49 & $10-25$ \\
\hline \multicolumn{4}{|l|}{ Width of orifice } & $22-42$ \\
\hline \multicolumn{5}{|l|}{ Length of avicularium: } \\
\hline Lateral-oral & 2 & 7.14 & (1) & $7-8$ \\
\hline Frontal & 94 & 10.13 & 1.99 & $7-16$ \\
\hline
\end{tabular}

The difference in mean lengths of proximal zooecia 
and distal and intermediate zooecia is not significant ( 0.05 level, Student's $t$ test) ; the mean width of proximal zooecia differs highly significantly from mean width of distal and intermediate zooecia $(0.01$ level, Student's $t$ test) .

Holotype, USNM 169245; paratypes, USNM 169246-169252; and 23 paratypes, USNM 169253; sample 1 . Nineteen paratypes, NSNM 169254, sample 2. Upper Eocene, about one-quarter mile north of Vaingana, Eua, Tonga, at altitude 400 feet.

Bifaxaria diaphyota resembles one or the other of two living species, B. papillata Busk and B. rugata (Harmer), in the following characters: (1) its numerous frontal avicularia on the more proximal zooecia imparting a papillose surface texture to the colony; (2) its frontal pitting; and (3) its small lateral-oral avicularia partly hidden in the peristome. It differs from both of these species in lacking large avicularia at points of branching. The distinctive median frontal groove of $B$. diaphyota distinguishes it from all other known species of the genus.

The marked ontogenetic differences between proximal and distal zooids in B. diaphyota is apparently attributable to the development of frontal avicularia, unlike the ontogenetic changes noted in $B$. bryani above. This development also resulted in an approximate doubling of the diameter of branches. Frontal pores appear to have been lost in the process, but the median frontal groove and the surface pitting remained as the frontal avicularia multiplied.

Family SPIROPORINIDAE Harmer, 1957

Genus SPIROPORINA Stoliczka, 1865

The suggestion (Brown, 1958, p. 55) that the type species of the genus Spiroporina, S. vertebralis Stoliczka, 1865, is a synonym of Eschara gracilis Lamarck, 1816, the type species of Porina d'Orbigny, 1852, seems unlikely because the nature of their median frontal pores is different (see Harmer, 1957, p. 846-848, and Brown, 1952, p. 191-192). The relation between the ascus and the median frontal pore in the two species, and in the genera that they represent, appears to be distinctive, even though Harmer (1957, p. 844) expressed doubt about the significance of the difference between ascopores and spiramina. In S. vertebralis, the ascus opens through the sinus in the primary orifice (Harmer, 1957, pl. 56, fig. 2), although that opening is enclosed within the peristome, and the sinus is thus presumably the homologue of the ascopore in Porina gracilis.

\author{
Spiroporina kondoi, n. sp. \\ Plate 4, figures 1, 2
}

Zoarium rigidly erect, delicate, dichc ${ }^{t}$ omously branched. Stems and branches slender, sulnylindrical, consisting of four to six alternating series of zooecia opening on all faces. Axes of stems and branches with longitudinal tubes.

Zooecia separated frontally by shallow, inconspicuous grooves in apparently distal zoarial fragments, absent in apparently proximal ones; in frontal view, elongate-rhombic, convexly rounded distclly, concavely rounded proximally. Zooecial length about three times width. Frontal shield slightly inflated; surface covered with short longitudinal grovves each containing a small pore; pores widely spaced, arranged in quincunx, those in marginal row ordinarily larger. Peristome completely hides primary orifice; moderately long, tubular, slightly inflated on ovicelled zooecia, free for as much as one-half the distance distal to spiramen, usually porforated proximolaterally by a pair of circular, slightly enlarged pores; free edge thin, cusped in distal zooecia, thick, rounded in proximal zooecia. Secondary orifice subcircular. Spiramen slightly larger than other medial frontal pores, surrounded by tubular, commonly protuberant collar.

Avicularia adventitious, represented by as many as five minute pits of irregular form distributed around free margins of apparently brolen peristomes. Pivotal structures not observed.

Ovicells completely immersed, apparent $\epsilon$ xternally only as swellings in distal parts of peristomes of ovicelled zooecia.

Zooecial dimensions (in $\mathrm{dk} \mu$ ) measured in frontal view on five zoarial fragments (holotyr? and 4 paratypes USNM 169257, 169258) are summarized as follows (mean and standard deviation given to two decimal places for purposes of calculation only) :

\begin{tabular}{lcccc}
\hline Dimension & $\begin{array}{c}\text { Number } \\
\text { measured }\end{array}$ & Mean & $\begin{array}{c}\text { Standard } \\
\text { deviation }\end{array}$ & $\begin{array}{c}\text { Observed } \\
\text { range }\end{array}$ \\
\hline $\begin{array}{l}\text { Length of zooecium } \\
\text { Width of zooecium }\end{array}$ & 34 & 103.89 & 14.39 & $82-132$ \\
$\begin{array}{l}\text { Length of orifice } \\
\quad\left(\begin{array}{c}\text { secondary) } \\
\text { Width of orifice }\end{array}\right.\end{array}$ & 42 & 42.54 & 3.93 & $34-51$ \\
$\quad$ (secondary) & 45 & 15.14 & 5.73 & $12-22$ \\
\hline
\end{tabular}

Holotype, USNM 169255, and 9 paratypes, USNM 169256 ; sample 2. Paratype, USNM 169257, 3 paratypes, USNM 169258, and 70 paratypes: USNM 169259, sample 1. Upper Eocene, about on?-quarter mile north of Vaingana, Eua, Tonga, at altitude 400 feet. 
Spiroporina kondoi resembles the living species S. brevitubulata Harmer, 1957, in its inconspicuous frontal pores placed in slitlike grooves; in $S$. brevitubulata, however, the colony is eight-serial, and the frontal wall supports numerous avicularia. The large lateral pores commonly present on the proximal part of the peristome distinguish $S$. kondo $i$ from all previously known species of Spiroporina. Superficially, S. kondoi resembles Tessaradoma boreale (Busk, 1860), a widespread living cool-water species, which, however, lacks axial tubes in its branches and has only marginal pores on its frontal shields.

\section{Spiroporina deliqua, $\mathrm{n} . \mathrm{sp}$. \\ Plate 5, figures 1, 2}

Zoarium rigidly erect, delicate, dichotomously branched. Stems and branches subcylindrical, consisting of transverse whorls composed of four zooecia each; zooecia opening on all four faces, those in adjacent whorls alternating in longitudinal position. Axes of stems and branches apparently without longitudinal tubes.

Zooecia without evident boundaries in frontal view, except for shallow depression separating zooecial whorls; interwhorl boundary forms V-shaped lobes directed proximally between laterally adjacent peristomes, thus marking lateral margins of zooecia. Zooecial length about three times width. Frontal shield inflated, closely and uniformly perforated with numerous small pores arranged in quincunx. Peristome completely hides primary orifice; moderately long, tubular, free more than half distance distal to spiramen on some zooecia, perforated with small pores similar to those on shield; free edge thin, slightly cusped. Secondary orifice subcircular. Spiramen much larger than other frontal pores, surrounded by prominent, tubular collar.

Avicularia adventitious, of two positions: peristomial and frontal. Peristomal avicularia represented by six or more minute pits of irregular form distributed around free margins of apparently broken peristomes. Frontal avicularia rarely present, placed just proximal to $V$ 's of interwhorl boundaries; oriented approximately longitudinally; rounded. Pivotal structures not observed.

Ovicells not found.

Zooecial dimensions (in $\mathrm{dk} \mu$ ) of five zoarial fragments (holotype and paratypes) are summarized as follows (mean and standard deviation given to two decimal places for purposes of calculation only) :

\begin{tabular}{lcccc}
\hline Dimension & $\begin{array}{c}\text { Number } \\
\text { measured }\end{array}$ & Mean & $\begin{array}{c}\text { Standard } \\
\text { deviation }\end{array}$ & $\begin{array}{c}\text { Observed } \\
\text { range }\end{array}$ \\
\hline $\begin{array}{l}\text { Length of zooecium } \\
\text { Width of zooecium }\end{array}$ & 42 & 93.06 & 13.09 & $76 .-124$ \\
$\begin{array}{l}\text { Length of orifice } \\
\quad \begin{array}{l}\text { (secondary) } \\
\text { Width of orifice }\end{array}\end{array}$ & 45 & 48.05 & 4.37 & $37-54$ \\
$\quad$ (secondary) & 48 & 12.60 & 1.81 & $10-18$ \\
\hline
\end{tabular}

Holotype, USNM 169260, paratype, USNM 16?261, and 3 paratypes, USNM 169262, sample 1. Upper Eocene, about one-quarter mile north of Vaingana, Eua, Tonga, at altitude 400 feet.

Spiroporina deliqua resembles the living species S. longicollis (Canu and Bassler, 1929) in its frontal perforations, long peristomes, and lack of axial tubes; it differs from that species in having fewer frontal avicularia and more slender branches with fewer zooecia per whorl. In both sets of characteristics, S. deliqua is similar to Porina tubulifera (MacGillivray, 1895), a species known from EoceneMiocene beds in Australia (Brown, 1958, p. 55) and from Oligocene beds in New Zealand (Brown, 1952, p. 193) ; the resemblance appears to be superficial, however, for in $P$. tubulifera the median frontal pore is an ascopore rather than a spiramen (Brown, 1952 , p. 192).

\section{Genus TESSARADOMA Norman, 1869 \\ Tessaradoma bifax, n. sp. \\ Plate 5, figures 4, 5}

Zoarium apparently rigidly erect; branching not observed in fragments studied. Stems subcylindrical, consisting of two alternating series of zooecia arranged back to back. Zoarial fragments apparontly from proximal parts of colonies have diameters almost twice those apparently from distal parts. Basal attachments not found.

Zooecia lack distinct frontal boundaries, even in least heavily calcified specimens found; in lateral view, roughly zigzag double line of apparently marginal pores probably limits interzooecial boundary. In frontal view, zooecial width about five-sixths length in distal fragments, nearly $11 / 2$ times length in proximal fragments. Frontal shield inflated, thick in all fragments studied; surface covered with discontinuous, irregularly longitudinal ridges, fine on distal zooecia, coarse on proximal zooecia; lateral and proximal margins of shields on distal zooecia apparently marked by single row of pores, lacking on proximal zooecia; circumoral region slightly attenuated to form peristome. Secondary orifice subterminal on frontal shield at apex of peristome, subcircular; in distal zooecia, proximal part of 
secondary orifice sinuate, the sinus almost isolated from rest of opening by a pair of proximolateral denticles in peristome; in proximal zooecia, sinus lacking. Secondary orifices of ovicelled zooecia not apparently different from those of nonovicelled zooecia.

Avicularia adventitious, a pair placed on lateral extremities of frontal shield in series with apparently marginal pores, at about mid-zooecial length ; lacking on proximal zooecia. Avicularian cavity rounded, without apparent pivotal structures.

Ovicells immersed in distal zooecia, apparent only from slight enlargement of peristomes of ovicelled zooecia and swellings in frontal shields of distal zooecia.

Zooecial dimensions (in $\mathrm{dk} \mu$ ) measured in frontal view on four zoarial fragments (holotype and paratypes) are summarized as follows (mean and standard deviation given to two decimal places for purposes of calculation only):

\begin{tabular}{lcccc}
\hline Dimension & $\begin{array}{c}\text { Number } \\
\text { measured }\end{array}$ & Mean & $\begin{array}{c}\text { Standard } \\
\text { deviation }\end{array}$ & $\begin{array}{c}\text { Observed } \\
\text { range }\end{array}$ \\
\hline $\begin{array}{l}\text { Length of zooecium } \\
\text { Width of zooecium: }\end{array}$ & 15 & 70.00 & 6.77 & $59-80$ \\
$\quad$ Distal zooecia & 8 & 60.08 & 2.01 & $59-65$ \\
$\quad \begin{array}{l}\text { Intermediate zooecia---- } \\
\quad \text { Proximal zooecia }\end{array}$ & 4 & 66.57 & 4.17 & $62-72$ \\
$\begin{array}{l}\text { Length of orifice } \\
\quad \text { (secondary) }\end{array}$ & 3 & 86.80 & 5.33 & $81-94$ \\
Width of orifice & 17 & 20.06 & 1.90 & $15-24$ \\
$\quad$ (secondary) & 17 & 21.94 & 2.01 & $18-26$ \\
Length of avicularium & 13 & 7.56 & 1.66 & $6-12$ \\
\hline
\end{tabular}

Tested by Student's $t$, the differences in mean widths of the distal, intermediate, and proximal zooecia are highly significant (0.01 level).

Holotype, USNM 169263, sample 2. Paratype, USNM 169264, and 2 paratypes, USNM 169265, sample 1. Upper Eocene, about one-quarter mile north of Vaingana, Eua, Tonga, at altitude 400 feet.

Tessaradoma bifax appears to be related to the living species T. striatum (Canu and Bassler, 1930), which differs from the Tongan species in having the frontal shields irregularly and coarsely grooved rather than ridged and the secondary oral sinus isolated as a spiramen in the distal zooecia and then persistent, though confluent with the orifice, in the proximal zooecia.

These two species and a third, T. bipatens Harmer, 1957, differ from the type species of Tessaradoma, T. boreale (Busk, 1860) in their biserial colonies and the intimate association or complete confluence of their spiramina with the secondary orifices. $T$. striatum was originally assigned by Canu and Bassler $(1930$, p. 31$)$ to their genus Diplonotos, the type species of which $(D$. costulatum Canu and Bassler,
1930, by original designation) belongs to Bifaxaria as that genus is constituted above. Examination of the syntypes (USNM 8504) of Diplonotos striatum reveals that the primary orifice, contrar: to the original description, lies at the base of a peristomial shaft that is very long in the heavily calcified parts of colonies, though the peristome is almost totally immersed in the thickened frontal shield. The sinuate opening described as a primary orifice thus is actually the secondary orifice, and, as mentioned above, this structure is isolated as a separate spiramen in distal zooecia (Canu and Bassler, 1930, pl. 10, fig. 3). With upgrowth of the peristome and surrounding frontal shield, the medial part of the bar separating the spiramen from the secondary orifice is discontinued so that the two openings are confluent in the more proximal zooecia. In T. bipatens, in which the peristome is less thoroughly immersed in tre frontal shield, the spiramen is a tube extending up the proximal side of the peristomial collar in both distal and proximal zooecia (Harmer, 1957, p. 853), thus linking the biserial species with $T$. boreale, in which the spiramen is removed from the secondary orifice completely.

The ontogenetic changes in T. bifax, though not so clearly shown in this fossil material, thus appear to parallel those shown by T. striatum and to some extent, those shown by $T$. boreale. These chenges are superficially similar to those noted above in species of Bifaxaria in that the diameters of stems approximately doubled by the thickening of the frontal shield. In the process, however, lateral $\varepsilon$ vicularia disappeared together with the apparently marginal pores, rather than multiplying as in the species of Bifaxaria.

Family SIPHONICYTARIDAE Harmer, 1957 Genus TUBITRABECULARIA Canu and Bassl $9 x, 1934$

Tubitrabecularia is one of the four genera the assignment of which by Bassler (1935, p. 34; 1953, p. G211) to the family Tubucellariidae Busk, 1884, was questioned by Harmer (1957, p. 824). Th family Siphonicytaridae was established by Harmor (1957, p. 892) for one of the four genera, Siphonicytara Busk, 1884, a living deep-water genus. A distinctive feature of Siphonicytara, the demarcation of the ascopore area by raised ridges, is also characteristic of Tubitrabecularia; however, additional ridge` are present in species of this genus, especially in the type species, T. elevata (Tenison-Woods, 1876) (see Waters, 1881, pl. 17, fig. 63). The frontal ridges of $T$. elevata greatly alter the frontal appearance of its highly calcified zooecia, making its morphnlogic interpretation difficult. 
Tubitrabecularia clypeata (Waters)

Plate 6, figure 2

Porina clypeata Waters, 1881, Geol. Soc. London Quart. Jour., v. 37 , p. 332 , pl. 17 , fig. 67.

Tubitrabecularia proditor Canu and Bassler, 1935, Smithsonian Misc. Colln., v. 93, p. 18, pl. 4, fig. 10.

Five poorly preserved zoarial fragments, all from sample 1, belong to Tubitrabecularia clypeata, which was described from lower Miocene beds (Balcombian Stage) at Mount Gambier, South Australia, and Muddy Creek, Victoria. The specimens are four- to tenserial, those with fewer zooecial series being subcylindrical, and those with more being slightly compressed. Australian specimens, for example, USNM 85887 from Muddy Creek, range from subcylindrical to highly compressed, and the holotype of $T$. proditor, USNM 85886, shows distalward flattening from a subcylindrical proximal end, perhaps the growth form of all fully developed colonies. There is no evidence in any of the material examined that the colonies were jointed (compare, Canu and Bassler, 1935, p. 18).

The zooecia in the Tongan specimens of $T$. clypeata are elongate and divided into two subequal frontal portions; a flat proximal area terminating distally in the tubular collar surrounding the ascopore, and an inflated distal peristome which is sessile for most of its length. The ridges demarcating these areas are less distinct in the Tongan specimens than in the Australian specimens, but this difference may be a result of preservation. The ascopore collar projects obliquely proximally, so that the ascopore faces proximally. A faint ridge runs distally from the ascopore up the midline of the peristome to the secondary orifice on some Tongan specimens (plate 6, fig. 2) ; this feature is not constant even in the better preserved Australian specimens.

The ascopore collar, in all material examined, rises from a slight depression and is bounded on either side by a small pore which seems to be in series with the larger pores that margin the peristome and the proximal frontal area. Lateral to each of the smaller pores is an adventitious avicularium of which the pointed rostrum extends slightly distally and up the side of the peristome of the laterally adjacent zooecium. Because of the lateral pore between it and the ascopore, the avicularium appears to be part of the zooecium whose orifice it flanks rather than of the zooecium whose ascopore it is near, as was assumed by Waters (1881, p. 332, pl. 17, fig. 67 ).

Ovicells were not found in the Tongan specimens. Frontally swollen areas on the holotype of $T$. proditor, interpreted as ovicells by Canu and Bassler
(1935, p. 18), appear to be solid masses of thick frontal shield.

Family SERTELLIDAE Jullien, 1903

Genus RETEPORELLINA Harmer, 1933 (?)

Reteporellina? sp.

Plate 6, figures 1, 3, 4

Twelve zoarial fragments from sample 1 and seven from sample 2, all poorly preserved, have zoarial and some zooecial features indicating that they may belong to Reteporellina.

The growth form of these specimens of Reterorellina? was apparently rigidly erect, unilaminate, dichotomously branched, and without anastomoses. The branches are two- or four-serial with indistinct zooecial boundaries rarely showing one or two proximolateral pores. The basal sides of the branches are tuberculate and have a few irregularly trans ${ }^{\text {re }}$ erse ridges.

Some of the badly worn peristomes have a labial pore and a rounded labial avicularium of about the same size as the pore, giving the secondary orifice a biperforate-appearing proximal lip. Evidence of oral spines or denticles is lacking. The few ovicells present are all broken, so their frontal morphology is not observable.

Besides the labial avicularia, apparently present on all zooecia, some zooecia, especially in the vicinity of ovicells, have larger avicularia placed proximolaterally on their frontal shields. The spatulate rostra of the frontal avicularia are directed laterally. Large spatulate avicularia are also present on the basal sides of some branches, placed in the axils of bifurcations with their rostra directed obliquely distalvrard.

In the absence of better preserved zooecial morphology, especially that of the ovicell, it is not possible to identify these specimens definitely with Reteporellina or to compare them with known species of that genus.

\footnotetext{
Family SCHIZOPORELLIDAE Jullien, 1883 Genus SCHIZOPORELLA Hincks, 1877

Schizoporella aff. S. macgillivrayi Canu and Bassler

Plate 5, figure 3
}

Two zoarial fragments, both from sample 1, appear related to Schizoporella macgillivrayi Canu and Bassler (1935, p. 29, pl. 9, fig. 5), which was described from the lower Miocene (Balcombian Stage) of Victoria, Australia. Like S. macgillivrayi, the Tongan specimens have transversely hexagonal zorecia separated frontally by salient ridges and have frontal shields closely perforated by small pores; these 
characters are better shown in the specimen illustrated by MacGillivray (1895, pl. 11, fig. 3), which Canu and Bassler (1935, p. 29) included in S. macgillivrayi, than they are in the holotype (USNM 85859). The growth form of the Tongan specimens, however, is erect rather than encrusting, the orifice is more broadly sinuate, and there is little tendency for the zooecial axes to be disarranged as they are in the holotype of $S$. macgillivrayi. Avicularia are lacking on the Tongan specimens, but, contrary to the original description of $S$. macgillivrayi, they are present laterally on the frontal shields of some zooecia on the holotype; this observation accords with the suggestion of Brown (1958, p. 59) that avicularia might be present on some material from Victoria.

Genus CHIASTOSELLA Canu and Bassler, 1934 (?)

Chiastosella? sp.

Plate 4, figure 3

One zoarial fragment from sample 2 , encrusting an unidentifiable piece of shell, may belong to Chiastosella.

One nearly complete zooecium and small parts of four others are preserved. The zooecium is rhombic and separated from the others by a distinct groove. Its frontal shield is inflated, perforated with large quincuncially arranged pores around all its margins and proximal to the orifice; the central imperforate portion is smooth. The interspaces between frontal pores tend to form radial ridges, as in $C$. porosa Canu and Bassler (1935, pl. 6, fig. 4). The orifice is semicircular distally, broadly sinuate proximally; its border is marked by a low peristome which supports four spine bases distally.

Lateral to this zooecium, the distal piece of the adjacent zooecium may have an ovicell. This structure is expressed frontally as a crescentic depression with a thick, perforate, raised ridge distal to the depression and suggests the immersed ovicells characteristic of the genus (see Brown, 1952, p. 219).

No avicularia were observed on this fragment.

In the absence of avicularia and of more definite ovicell structure, it is not possible to identify this fragment certainly as Chiastosella or to compare it with any known species of the genus. Species of this genus have been recorded from Australia and New Zealand, ranging from Eocene to Holocene (Brown, 1958, p. 57).

Family TETRAPLARIIDAE Harmer, 1957 Genus TETRAPLARIA Tenison-Woods, 1879

The fossil species referred to the genus Tetrapla- ria, including the type species, T. australis TenisonWoods, 1879, from beds of Eocene-Miocere age in Australia, show more morphologic diversity than allowed in Harmer's (1957, p. 1053) diagnosis, which apparently was based only on studies of Holocene species. Some of this variation, especially in colony form, probably should not be included in the concept of Tetraplaria.

Unlike T. australis and all the living species, some fossils have not yielded skeletal evidence of an erectjointed colony form, that is, internodes beginning with a bipartite connecting tube proximally and ending with a pair of bipartite bases rami distally. Cellaria schreibersi Reuss, 1848, from the upper. Eocene of Italy, placed in Tetraplaria by Canu and Bassler (1920, p. 367) and Braga (1963, p. 39; 1965, p. 231), not only lacks these structures but also exhibits dichotomous branching within single calcifod fragments (Reuss, 1848, p. 63). Tetraplaria caudifera Canu and Bassler, 1920, from the upper Eocene of South Carolina, and Smittia centralis var. laevigata Waters, 1881 (presumably the taxon callec Smittea lacvigata Waters in Canu and Bassler's 1923, p. 395, list of species of Tetraplaria), from the lower Miocene of Australia, also lack nodal structures and, additionally, have frontal pores limited to the margins of the shield, rather than dispersed uniformly over it as in all other fossil and all living species of Tetraplaria. These three species should probably be assigned to other genera. Examination of the syntypes of $T$. caudifera (USNM 64071) suggests that they may be conspecific with Hippopleurifera costulata (Canu and Bassler, 1920).

Brooding arrangements are variable in Tetraplaria. Hyperstomial ovicells are known in most species, including T. australis (see Brown, 1958, p. 58). Exceptions, in addition to the three nonjointer species mentioned above, are T. tuberculata Canu $\varepsilon$ nd Bassler, 1920, from the upper Eocene of Florida, and $T$. immersa (Haswell, 1880), a living species from Australia, which has inflated brooding zooids (Harmer, 1957, p. 1055). In T. australis the ovicell is deeply immersed in the distal zooecium (Brown, 1958, p. 58), whereas in all other ovicelled species it is prominent, especially so in the Florida late Eocene snecies $T$. petila Cheetham, 1963, and T. obesa Cheetham, 1963.

In three living species, T. ventricosa (Haswell, 1880 ), from the Indo-Pacific, T. dichotoma (Osburn, 1914) from the Gulf of Mexico and Caribbean, and T. gilbertensis (Maplestone, 1909), from the Gilbert Islands, Hawaii, and the Galapagos, the orifices of ovicelled zooecia are larger than those of nor ovicelled zooecia. This dimorphism has not been noted pre- 
viously in fossils referred to Tetraplaria, but it is prominent in one of the two Tongan species, $T$. simata, n. sp.

Apart from the three apparently nonjointed species, which seem not to belong in Tetraplaria, avicularia are known in T. australis. According to Brown $(1958$, p. 58$)$, specimens having avicularia are limited to the earlier populations of this species. The Tongan specimens, which are approximately coeval with the earliest populations of $T$. australis, do not have avicularia.

$$
\begin{gathered}
\text { Tetraplaria simata, } \text { n. sp. } \\
\text { Plate } 7 \text {, figures } 1,4,5
\end{gathered}
$$

Zoarium erect-jointed, consisting of quadriserial internodes of four or five alternating pairs of auto-

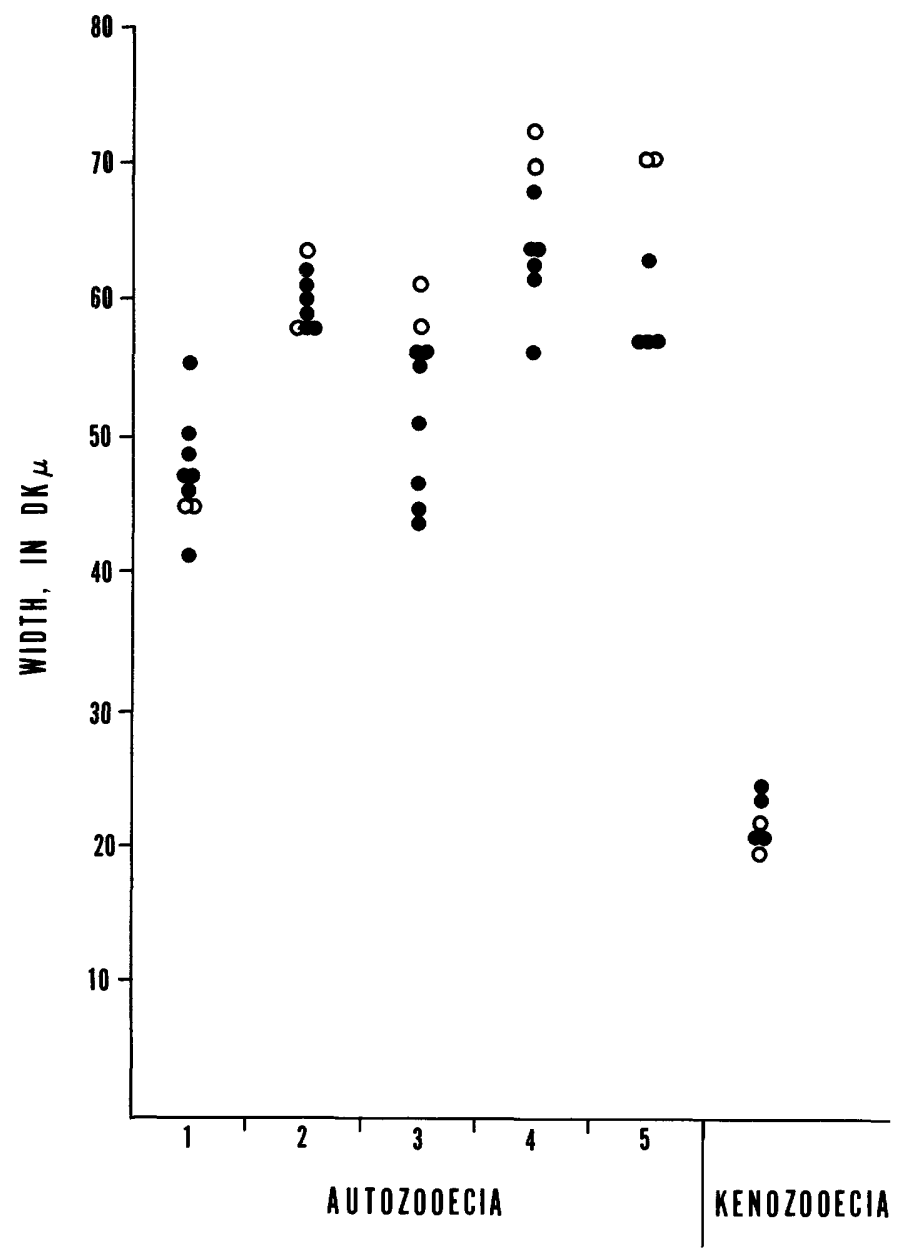

FIGURE 6.-Variations in width of successive pairs of autozooecia (1-5) and aistal kenozooecia in five internodes of Tetraplaria simata, n. sp. Open circles, holotype (third pair of autozooecia ovicelled); closed circles, paratypes. One paratype has only four pairs of autozooecia preceding kenozooecia. A few zooecia in paratypes were not measured because of poor preservation. zooecia and one pair of distal kenozooecia becring bases rami ; one pair of autozooecia can bear ovicells. Internodes stubby, tapered proximally, blunt distally, the proximal two-thirds to three-fourths slightly flattened in plane parallel to frontal surfaces of evennumbered pairs of zooecia; these zooecia thus are wider than the first two odd-numbered pairs (fic: 6). Proximal end of internode is an imperforate, bipartite tube, slightly flattened in same plane as internode, formed from attenuated caudal portions of first pair of zooecia. Distal end of internode is a pair of elliptical bases rami with long axes oblique to axis of internode, on small kenozooecia slightly below distal margins of last pair of autozooecia, and, in some specimens, recessed below frontal surfaces of autozooecia proximal to them. Opening of basis rami bipartite.

Autozooecia separated frontally by narrow ridges. Zooecial length decreases distally within each internode (fig. 7) ; first through third pairs of zonecia show marked decrease in length, fourth pair no significant change, and fifth pair, where present, slight decrease. Widths of first and third pairs of zorecia about five-sixths those of second, fourth, and (n'here present) fifth pairs; widths of ovicelled zooecia and of all succeeding zooecia greater than those of corresponding pairs in nonovicelled internodes (fig. 6). First pair of zooecia elongate-claviform; second pair rhombic with distal corner convexly rounded; all following pairs transversely hexagonal, rounded concavely on proximal side and convexly on distal side. Frontal shield inflated, uniformly perforate ercept on caudal portion of first pair ; pores small, numerous, quincuncially arranged. Orifice terminal on frontal shield, very slightly inclined distally; distal portion semicircular; proximal sinus broadly rounded, apparently lacking condyles; orifices of nonovicelled zooecia about four-fifths as large as those of ovicelled zooecia. Oral spines lacking.

Kenozooecia rounded-rectangular; about one-third as large as autozooecia; distal half occupied by oblique basis rami; proximal half covered with inflated, finely perforate frontal shield.

Ovicells present on both zooecia of third pair in some internodes (seen in one internode); hyperstomial, prominent, covering proximal five-sixths of distal zooecium. Frontal cover uniformly and finely perforate, except for semicircular strip around orifice; set off from frontal shields of distal and prorimal zooecia by narrow ridges.

Avicularia lacking.

Zooecial dimensions (in $\mathrm{dk} \mu$ ) measured in frontal view on five internodes (holotype and paratypes) are 


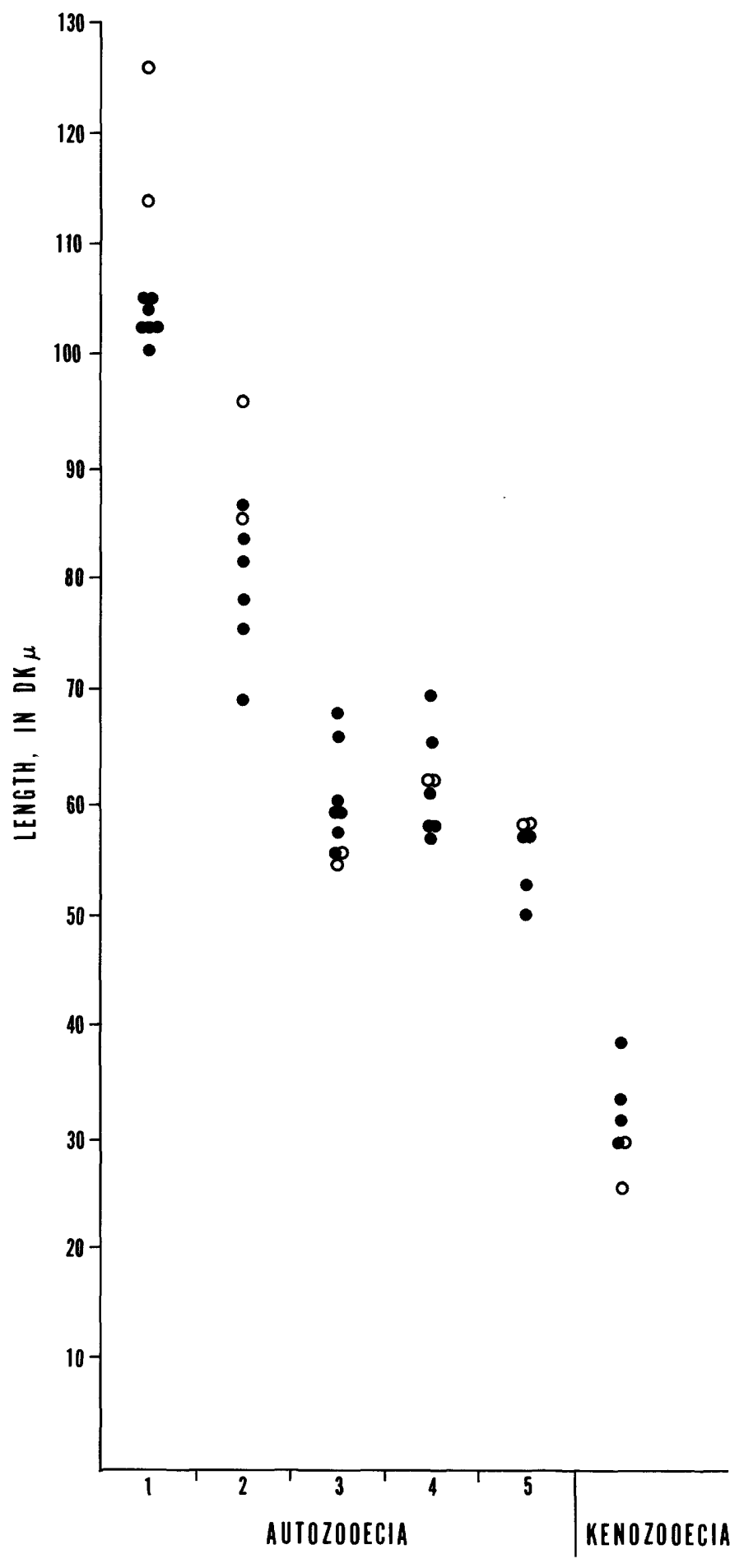

FIGURE 7.-Variations in length of successive pairs of autozooecia (1-5) and distal kenozooecia in five internodes of Tetraplaria simata, n. sp. Specimens and symbols as in figure 6 .

summarized as follows (mean and standard deviation given to two decimal places for purposes of calculation only) :

\begin{tabular}{|c|c|c|c|c|}
\hline Dimension & $\begin{array}{l}\text { Number } \\
\text { measured }\end{array}$ & Mean & $\begin{array}{l}\text { Standard } \\
\text { deviatior }\end{array}$ & $\begin{array}{c}\text { Observed } \\
\text { range }\end{array}$ \\
\hline \multicolumn{5}{|l|}{ Length of autozooecium: } \\
\hline First pair & 9 & 105.93 & 7.35 & $100-124$ \\
\hline Second pair & 8 & 80.85 & 7.04 & $69-94$ \\
\hline Third pair & 9 & 59.17 & 4.19 & $55-67$ \\
\hline Fourth pair & 8 & 62.48 & $\mathbf{5 . 0 2}$ & $56-71$ \\
\hline Fifth pair & 6 & 54.74 & 2.89 & $50-57$ \\
\hline \multicolumn{5}{|l|}{ Width of autozooecium: } \\
\hline First pair & 9 & 46.67 & 3.57 & $41-55$ \\
\hline Second pair & 8 & 59.54 & .98 & $58-62$ \\
\hline Third pair. & 9 & 53.85 & 3.87 & $46-60$ \\
\hline Fourth pair & 8 & 64.16 & 4.48 & $56-71$ \\
\hline Fifth pair & 6 & 62.58 & 6.01 & $57-71$ \\
\hline \multicolumn{5}{|l|}{ Length of zooecial orifice: } \\
\hline Nonovicelled zooecia & 36 & 15.89 & .70 & $14-17$ \\
\hline Ovicelled zooecia & 2 & 18.90 & .42 & $18-19$ \\
\hline \multicolumn{5}{|l|}{ Width of zooecial orifice: } \\
\hline Nonovicelled zooecia & 36 & 16.50 & .82 & 14-18 \\
\hline Ovicelled zooecia & 2 & 19.74 & .42 & $19-20$ \\
\hline Length of ovicell & 2 & 50.40 & .00 & 50 \\
\hline Width of ovicell & 2 & 54.60 & 4.20 & $50-59$ \\
\hline Length of kenozooecium & 6 & 30.94 & 3.83 & 25-38 \\
\hline Width of kenozooecium & 6 & 21.14 & 1.49 & $19-24$ \\
\hline
\end{tabular}

The differences between means were tested by Student's $t$ with the following results (significant $=0.05$ level $;$ highly significant $=0.01$ level $)$ :

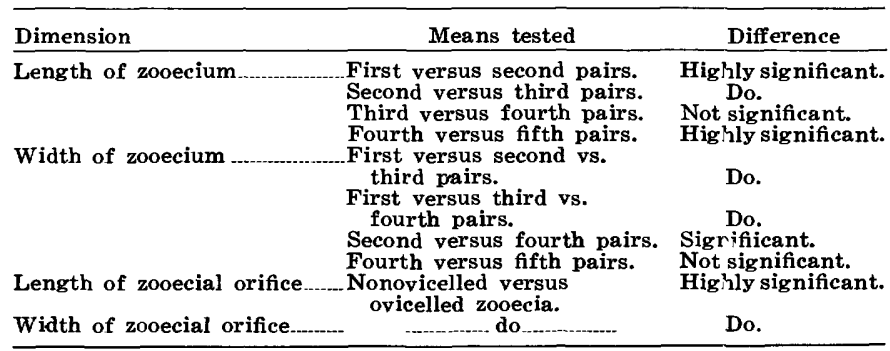

Holotype, USNM 169276; paratype, USNM 169277; sample 2. Paratype, USNM 169278, and 2 paratypes, USNM 169279, sample 1. Upper. Eocene, about one-quarter mile north of Vaingana, Eua, Tonga, at altitude 400 feet.

Tetraplaria simata is distinguished by its slightly flattened internodes having the even-numbered pairs of autozooecia distinctly wider than the first two oddnumbered pairs; by the regular distalward decrease in lengths of the first three pairs of autozocecia in an internode; and by the combination of prominent ovicells, broadly sinuate orifices which are dinnorphic in association with brooding, and ridges separating zooecia. If the limited variation in number of autozooecial pairs per internode, four or five, is significant in this small sample, this character would also differentiate $T$. simata from all other known species of the genus.

Although the widths of the first four pairs of autozooecia of $T$. simata (fig. 6) differ significantly statistically, those of the first and third pairs overlap broadly, as do those of the second, fourth, and fifth pairs. Except for the two ovicelled zooecia forming the third pair in one internode, there is almost no overlap between the two groups of autozooc.cial pairs. 
This difference in width is correlated with the flattening of the proximal part of the internode.

The third to fifth pairs of autozooecia in the ovicelled internode are wider than their counterparts in the nonovicelled internodes (fig. 6). The greater width is apparently a direct accommodation to the size of the ovicell, as it is restricted to the ovicelled and more distal zooecia. Thus, the ovicelled internode began growth with zooids like the first pair of zooids in the nonovicelled internodes and then, beginning with the ovicelled zooids, developed a different morphology.

The successive, pronounced distalward decreases in the lengths of the first three pairs of autozooecia within each internode (fig. 7) appear to follow an astogenetic gradient. If one can assume that all of the internodes beyond the unknown encrusting base of the colony had the form of the specimens described here, the astogenetic zonation in T. simata is of the cyclic type described by Boardman, Cheetham, and Cook (1970, p. 300, fig. 4), with each internode comprising subsequent zones of both astogenetic change and astogenetic repetition. The number of generations of zooids within a zone of repetition in T. simata, however, appears drastically limited compared to other cheilostomes in which cyclic zonation has been described.

In an internode having just four pairs of autozooecia preceding the distal kenozooecia, the zone of astogenetic repetition appears to consist of the fourth pair of autozooecia, which do not differ significantly in length from the third pair, and the pair of kenozooecia, which can be considered positional polymorphs similar to zooecia making up monticules in trepostomes (Boardman and others, 1970, p. 303). Where present, a fifth pair of autozooecia would thus also be included in the zone of repetition, and their slight, but statistically significant, decrease in length from the fourth pair could be regarded either as a chance variation because of the small sample or as a further expression of positional polymorphism. That this difference may be a chance variation is suggested by the broad overlap between the fourth and fifth pairs, as compared to no overlap of the first three pairs (fig. 7).

Alternatively, the slight decrease in length of the fifth pair of autozooecia could be considered the start of a series of astogenetic changes continuing into the next internode. This interpretation seems unlikely because it would restrict the kenozooecia to zones of change and because the zone of change would include zooecia showing first a decrease in length (fifth pair of autozooecia to kenozooecia), then an increase (kenozooecia to first pair of autozooecia in next internode), and again a decrease (first to third rairs of autozooecia).

The decreasing lengths of autozooecia in eack internode reduce the distances between the distal margins of alternating pairs toward the distal end of the internode. If all pairs of zooids were the same length, the last two pairs would be half a zooecial lengtr. out of phase, and the kenozooids would have to be more than half as long as the autozooids in order to hold the bases rami beyond the ends of the last pair of autozooids. In $T$. simata the kenozooecia are less than a third as long as the longest autozooecia (fig. 7). In other species of Tetraplaria (see T. cf. T. turgida below), the autozooecia remain half a length out of phase and are followed by a relatively longer pair of kenozooecia.

\section{Tetraplaria cf. T. turgida Tewari and Srivastava}

Plate 7, figures 2, 3

?Tetraplaria turgida Tewari and Srivastava, 1967, Jour. Geol. Soc. India, v. 8 , p. 26 , text-fig. $2(4,4 a)$.

Three specimens, all from sample 2, may belorg to Tetraplaria turgida which was described from the middle Eocene (Kirthar Stage) of Kutch, India.

Although not shown in Tewari and Srivastava's (1967) drawings, frontal perforations seem to be implied in their description (frontals "covered by tremocysts," p. 27). All the Tongan specimens have large, prominent, evenly distributed frontal pores.

One complete internode, consisting of five pairs of autozooecia plus a distal pair of kenozooecia each bearing a bipartite basis rami, has ovicells. T'ose are borne on both zooecia of the third pair, as are those on the specimen illustrated by Tewari and Srivastava, and as in the latter, the ovicells are prominent, rather than immersed in the distal zooecium.

Tewari and Srivastava compared this species with $T$. australis in which the ovicells are deeply immersed in the distal zooecium (Brown, 1958, p. 58). T. australis also has the frontal shield covered with fine tubercles between which are exceedingly small pores, which were overlooked in Tenison-Woods' (1879, p. 61) original description, and has the orifice interrupted proximally by a narrow, cleftlike sinus.

The Tongan specimens, and presumably the Indian specimens, more closely resemble another Austrelian species, T. pedunculata (MacGillivray, 1895), than they do T. australis. In T. pedunculata, the frcntal shield is coarsely perforate and the ovicell (present in USNM 169283, Balcombian, Mitchell River, Pairnesdale, Victoria; not previously noted) is prominent; the oral sinus, however, is narrow, and the zooecia are separated by prominent ridges. 
The internodes of the Tongan material appear to consist of variable numbers of autozooecial pairs. In addition to the five-paired complete internode, one specimen broken at both ends has six pairs, and the third, seemingly missing only a small part of the proximal zooecia and preserving the bases rami distally, shows only three pairs. In this respect, the Tongan specimens resemble living species of Tetraplaria, such as T. ventricosa (Haswell, 1880), in which Harmer (1957, p. 1054) described single colonies having the number of pairs of zooecia per internode ranging from one to ten or more.

\section{REFERENCES CITED}

Asano, Kiyoshi, 1939, Limestones of the South Sea Islands under the Japanese Mandate: Yabe Jubilee Pub., v. 1, p. $537-550$.

Bassler, R. S., 1935, Bryozoa, in Quenstedt, Werner, ed., Fossilium Catalogus; 1, Animalia, pt. 67: The Hague, W. Junk, 229 p.

__ 1953, Bryozoa, in Moore, R. C., ed., Treatise on invertebrate paleontology, Part G: Lawrence, Kans., Kansas Univ. Press and Geol. Soc. America, 253 p.

Boardman, R. S., and Cheetham, A. H., 1969, Skeletal growth, intracolony variation, and evolution in Bryozoa; a review: Jour. Paleontology, v. 43, p. 205-233, pls. 27-30, 8 figs.

Boardman, R. S., Cheetham, A. H., and Cook, P. L., 1970, Intracolony variation and the genus concept in Bryozoa, in North American Paleontological Convention, Chicago, 1969, Proceedings: Lawrence, Kans., Allen Press, p. 294-320, 12 figs.

Braga, Giampietro, 1963, I Briozoi del Terziario veneto: Soc. paleont. italiana Boll., v. 2, p. 16-55, pls. 2-5, 9 figs.

1965, Briozoi dell'Oligocene di Possagno (Trevigiano occidentale) : Soc. paleont. italiana Boll., v. 4, p. 216-244, pls. 28-30.

Brown, D. A., 1952, The Tertiary cheilostomatous Polyzoa of New Zealand: London, British Mus. (Nat. History), 405 p., 296 figs.

1958, Fossil Cheilostomatous Polyzoa from south-west Victoria: Victoria Geol. Survey Mem., no. 20, 83 p., 83 figs.

Burdon-Jones, C., and Tambs-Lyche, Hans, 1960, Observations on the fauna of the North Brattholmen stone-coral reef near Bergen: Bergen Univ. Arbok, Mat.-Naturv. serie no. 4, p. 1-24.

Busk, George, 1881, List of Polyzoa collected by Captain H. W. Feilden in the North-Polar Expedition, with descriptions of new species: Linnean Soc. Jour., Zoology, v. 15, p. 231-241, pl. 13.

1884, Report on the Polyzoa: Report of the Scientific Results of the Exploring Voyage of H.M.S. "Challenger", 1873-1876, Zoology, v. 10, pt. 30, 216 p., 36 pls., 59 figs.

Calvet, Louis, 1931, Bryozoaires provenant des campagnes scientifiques du Prince Albert I de Monaco: Résultats des Campagnes Scientifiques, Monaco, pt. 83, p. 1-152, 2 pls.

Canu, Ferdinand, and Bassler, R. S., 1920, North American early Tertiary Bryozoa: U.S. Natl. Mus. Bull. 106, 879 p., pls. 1-162, 279 figs. 1928a, Fossil and recent Bryozoa of the Gulf of Mexico region: U.S. Natl. Mus. Proc., v. 72, art. 14, 199 p., 34 pls., 35 figs.

-1928b, Bryozoaires des Iles Hawaii: Soc. Sri. Seine et Osie Bull., Sér., 2, v. 8, p. 1-56, pls. 1-11.

1929, Bryozoa of the Philippine region: U.S. Natl. Mus. Bull, 100, v. 9, 685 p., 94 pls. 224 figs.

1930, The bryozoan fauna of the Galapagos Islands: U.S. Natl. Mus. Proc., v. 76, art. 13, 78 p., 14 pls., 13 figs.

1935, New species of Tertiary cheilostome Bryozoa from Victoria, Australia: Smithsonian Misc. Colln., v. 93, no. 9,54 p., 9 pls.

Cheetham, A. H., 1959, Bryozoa, in Kornicker, L. S., and others, Alacran Reef, Campeche Bank, Mexico: Inst. Marine Sci. Pub., v. 6, p. 1-22.

-1963, Late Eocene zoogeography of the eastern Gulf Coast region: Geol. Soc. America Mem. 91, 113 p., 3 pls., 34 figs.

Cole, W. S., 1950, Larger Foraminifera from the Palau Islands: U.S. Geol. Survey Prof. Paper 221-B, p. 21-31. 1957a, Larger Foraminifera in Part 3, Paleontology of Geology of Saipan, Mariana Islands: U.S. Geol. Survey Prof. Paper 280-I, p. 321-360.

1957b, Larger Foraminifera from Eniwetok Atoll drill holes: U.S. Geol. Survey Prof. Paper 260-V, p. 743-784 [1959].

1960, Upper Eocene and Oligocene larger Foraminifera from Vitu Levu, Fiji: U.S. Geol. Survey Prof. Paper 374-A, 7 p. [1961].

1970, Larger Foraminifera of late Eocen? age from Eua, Tonga: U.S. Geol. Survey Prof. Paper 640-B, p. B1B17, pls. 1-5.

Cook, P. L., 1967, Polyzoa (Bryozoa) from West Africa, the Pseudostega, the Cribrimorpha, and some As:ophora Imperfecta: British Mus. (Nat. History) Bull., Zoology, v. 15, p. 321-351, pls. 1-2, 14 figs.

1968, Bryozoa (Polyzoa) from the coasts of tropical West Africa: Atlantide Rept. no. 10, (Scientific results of the Danish expedition to the coasts of tropical West Africa 1945-1946), Copenhagen, Danish Science Press, Ltd., p. 115-262, pls. 8-11,2 figs.

Furnestin, J., 1960, Hydrologie de la Méditerranée occidentale (Golfe du Lion), Mer Catalane, Mer d'Alboran (Corse orientale), 14 juin-20 juillet 1957: Inst. Sc'ontifique et Technique des Peches Maritime, Revue des travaux, v. 24, p. 5-119.

Gautier, Y. V., 1962, Recherches écologiques sur les Bryozoaires chilostomes en Mediterrannée occidentale: Recueil des travaux de la Station marine d'Endoume Bull. 24, pt. 38, p. 5-434, 91 figs.

Ghiurca, Virgil, 1966, The Tortonian Bryozoa frcm Talmacel and Cisnadioara (Sibiu-VIII) : Babes-Bolyai TJniv. Studia Series Geologia-Geographia, no. 1, p. 99-104, 2 figs. (In Rumanian, English summary.)

Guest, N. J., 1959, Geological mapping, Tonga: Fiji Geol. Survey Dept., Ann. Rept. for 1958, Council Paper 17, p. 3.

Harmer, S. F., 1923, On cellularine and other Polyzoa: Linnean Soc. London Jour., v. 35, p. 293-361, pls 16-19.

1926, The Polyzoa of the Siboga Expedition, pt. 2, Cheilostomata Anasca: Leyden, Siboga Expedition Repts., v. $28 \mathrm{~b}$, p. $181-501$, pls. $13-34,23$ figs. 
1957, The Polyzoa of the Siboga Expedition, pt. 4, Cheilostomata Ascophora II: Leyden, Siboga Expedition Repts., v. 28d, p. 641-1147, pls. 42-74, 69 figs.

Hastings, A. B., 1966, Observations on the type-material of some genera and species of Polyzoa: British Mus. (Nat. History) Bull., Zoology, v. 14, p. 57-78, 1 pl.

Haswell, W. A., 1880, On some Polyzoa from the Queensland coast: Linnean Soc. New South Wales Proc., v. 5, p. 3344, 3 pls.

Heller, Camil, 1867, Die Bryozoen des adriatischen Meeres: Verh. Zool.-Bot. Wien, v. 17, no. 4, p. 77-136, pls. 1-6.

Hincks, Thomas, 1880, On new Hydroida and Polyzoa from Barents Sea: Annals and Mag. Nat. History, ser. 5, v. 6, p. 277-286, pl. 15.

Hoffmeister, J. E., 1932, Geology of Eua, Tonga: Bernice P. Bishop Mus. Bull. 96, 93 p.

Jullien, Jules, and Calvet, Louis, 1903, Bryozoaires provenant des campagnes de "L'Hirondelle" (1886-1888) : Résultats des Campagnes Scientifiques, Monaco, pt. 23, 188 p., 18 pls.

Kirchenpauer, G. H., 1869, Beschreibung neuer Bryozoen: Mus. Godeffroy Hamburg, Catalog, v. 4, p. 14-24, 118-119.

Kirkpatrick, Randolph, 1888, Polyzoa of Mauritius: Annals and Mag. Nat. History, ser. 6, v. 1, p. 72-84, pls. 7-10.

Kluge, G. A., 1962, Mshchanki severnikh morei SSSR: Akad. nauk SSSR, Opredeliteli po Faune SSSR, Izdavaemye Zoologicheskim Institutom, v. 76, 584 p., 404 figs.

Labracherie, Monique, 1968, Quelques Bryozoaires cheilostomes de la Falaise de Handia (Biarritz, France), in Annoscia, Enrico, ed., Proceedings of the First International Conference on Bryozoa: Soc. Italiana Sci. Nat. Atti, v. 108, p. 312-326, pls. 7-10.

Lagaaij, Robert, 1968, First fossil finds of six genera of Bryozoa Cheilostomata, in Annoscia, Enrico, ed., Proceedings of the First International Conference on Bryozoa: Soc. Italiana Sci. Nat. Atti, v. 108, p. 345-360, pls. 11-12, 4 figs.

Lagaaij, Robert, and Gautier, Y. V., 1965, Bryozoan assemblages from marine sediments of the Rhône delta, France: Micropaleontology, v. 11, p. 39-58, 34 figs.

LeDanois, Edouard, 1948, Les profondeurs de la mer; Trente ans de recherches sur la faune sous-marine au large des côtes de France: Paris, Payot, 303 p., 8 pls., 56 figs.

Levinsen, G. M. R., 1909, Morphological and systematic studies on the cheilostomatous Bryozoa: Copenhagen, Nationale Forfatteres Forlag, 431 p., 27 pls., 6 figs.

MacGillivray, P. H., 1880, Polyzoa, in McCoy, Frederick, Prodomus of the zoology of Victoria, decade 5, p. 27-52, pls. $45-49$.

1895, A monograph of the Tertiary Polyzoa of Victoria: Royal Soc. Victoria Trans. and Proc., n.s., v. 4, p. 1-166, pls. 1-22.

Manzoni, Angelo, 1877, Bryozoaires du Pliocene Superieur de l'Ile de Rhodes: Soc. Géol. France Mém., ser. 3, v. 1, p. 59-72, pls. 4-5.

Maplestone, C. M., 1900, Further descriptions of the Tertiary Polyzoa of Victoria: Royal Soc. Victoria Proc., v. 12, p. 162-169, pls. 17-18.

1909, Polyzoa from the Gilbert Islands: Royal Soc. Victoria Proc., n.s., v. 21 , p. $410-419$, pls. $26-28$.
Maturo, F. J. S., Jr., 1968, The distributional pattern of the Bryozoa of the east coast of the United States exc'usive of New England, in Annoscia, Enrico, ed., Proceedings of the First International Conference on Bryozoa: Soc. Italiana Sci. Nat. Atti, v. 108, p. 261-284, 8 figs.

Nordgaard, Ole, 1900, Polyzoa: Den Norske Nordhavs-Expedition 1876-1878, v. 27, 33 p., 1 pl.

1905, Hydrographical and biological investigaticns in Norwegian fiords: Bergen, Bergens Museum, 254 p., 21 pls.

1918, Bryozoa from the Arctic Regions: Troms $\phi \mathrm{Mu}-$ seums Aarshefter, v. 40, no. 1, 99 p., 11 figs.

1927, The Folden Fiord: Troms $\phi$ Museums Skrifter, v. 1 , pt. 9,10 p.

Norman, A. M., 1894, A month on the Trondhjem Fjord: Annals and Mag. Nat. History, ser. 6, v. 13, p. 112-133, pls. 6-7.

1909, The Polyzoa of Madeira and neighbouring islands: Linnean Soc. London Jour., Zoology, v. 30, p. 27!-314, pls. 33-42.

O'Donoghue, C. H., 1924, The Bryozoa (Polyzoa) collected by the S.S. "Pickle": Union of South Africa Fisheries and Marine Biol. Survey, rept. 3, 63 p., 4 pls.

Osburn, R. C., 1914, The Bryozoa of the Tortugas Is'ands, Florida: Carnegie Inst. Washington Pub. 182, p. 181-222, 23 figs.

-1940 , Bryozoa of Puerto Rico with a resumé of the West Indian bryozoan fauna: Sci. Survey of Puerto Rics and the Virgin Islands (New York Acad. Sci.), v. 16, p. 321486,9 pls.

1952, Bryozoa of the Pacific coast of America, pt. 2, Cheilostomata-Ascophora: Allan Hancock Pacific Exped. Repts., v. 14, p. 271-611, pls. 30-64.

Pergens, Edouard, 1887, Pliocäne Bryozoën von Rhodos: K. Naturh. Hofmuseums, Wien, Annalen, v. 2, p. 1-34, pl. 1.

Pourtalés, L. F., de, 1874, Crinoids and Corals (Zoological results of the Hassler Expedition) : Harvard College, Mus. Comp. Zoology Mem., v. 4, p. 27-49, pls. 6-10.

Reuss, A. E., 1848, Die fossilen Polyparien des Wiener Tertiärbeckens: Haidingers Naturw. Abh. Wien, v. 2, 109 p., 11 pls.

Robertson, Alice, 1921, Report on a collection of Bryozoa from the Bay of Bengal and other Eastern Seas: Indiar Museum Rec., v. 22, pt. 1, no. 8, p. 33-65, 11 figs.

Ryland, J. S., 1963, Systematic and biological studies on Polyzoa (Bryozoa) from western Norway: Sarsia, v. 14, p. 1-59, 14 figs.

Sars, Michael, 1851, Beretning om en zoologisk Reise i Sommern 1849 i Lofoten og Finnmarken: Nytt Mag. Naturv., v. 6, p. 121-211.

-1862, Beskrivelse over nogle norske Polyzoer: Vidensk. Selsk. Christiania Fordh., p. 141-167.

Schopf, T. J. M., 1968, Generalizations regarding the Phylum Ectoprocta in the deep-sea $(200-6000 \mathrm{~m})$; in Anroscia, Enrico, ed., Proceedings of the First International Conference on Bryozoa: Soc. Italiana Sci. Nat. Atti, v. 108, p. 152-154.

Schopf, T. J. M., 1969, Geographic and depth distribution of the Phylum Ectoprocta from 200 to 6,000 meters: Am. Philos. Soc. Proc., v. 113, p. 464-474, 4 figs.

Schwarzbach, Martin, 1963, Climates of the past, an introduction to paleoclimatology: London, Van Nos'rand, $328 \mathrm{p}$. 
Silén, Lars, 1935, Bryozoa from the Skager Rack, with notes on the genus Triticella Dalyell: Arkiv för Zoologi, v. 28a, no. 16, p. $1-10$.

Smitt, F. A., 1868, Bryozoa marina in regionibus arcticis et borealibus viventia recensuit: Kgl. Svenska Vetensk.Akad. Förh., v. 24, no. 6, p. 443-487.

1873, Florida Bryozoa, collected by Count L. F. de Pourtales: Kgl. Svenska Vetensk-Akad. Handl., v. 11, p. $3-83$, pls. 1-13.

Tenison-Woods, J. E., 1879, On some Australian Tertiary fossil corals and Polyzoa: Royal Soc. New South Wales Jour. and Proc., v. 12, p. 57-61, 1 pl.

Tewari, B. S., and Srivastava, I. P., 1967, On some fossil Bryozoa from India: Geol. Soc. India Jour., v. 8, p. 18-28, 2 figs.

Thornely, L. R., 1905, Report on the Polyzoa, in Herdman, W. A., Report on the Pearl Oyster Fisheries, Gulf of Manaar, Supp. Rept. 26, p. 107-130, pl. 1.
-1907, Report on the Polyzoa in the collection of the Indian Museum: Indian Mus. Calcutta Rec., v. 1, p. 179196, 8 figs.

Todd, Ruth, 1970, Smaller Foraminifera of late Eocene age from Eua, Tonga: U.S. Geol. Survey Prof. Priper 640-A, p. A1-A23, pls. 1-8, 4 figs.

Waters, A. W., 1881, On fossil cheilostomatous Brrozoa from South-West Victoria, Australia: Geol. Soc. London Quart. Jour. v. 37, pt. 2, no. 146, p. 309-347, pls. 14-18. 1882, On fossil cheilostomatous Bryozoa from Mount Gambier, South Australia: Geol. Soc. Lonton Quart. Jour., v. 38, pt. 4, no. 152, p. 257-276, pls. 7-9.

1883, Fossil cheilostomatous Bryozoa from Muddy Creek, Victoria: Geol. Soc. London Quart. Jour., v. 39, pt. 2, no. 154, p. 423-443, pl. 12, 3 figs.

1888, Supplementary report on the Polyzoa collected by H.M.S. "Challenger" during the years 1873-1876: Challenger Exped. Rept. Zoology, pt. 79, p. 1-41, pls. 1-3. 


\section{INDEX}

[Italic page numbers indicate major references and descriptions]

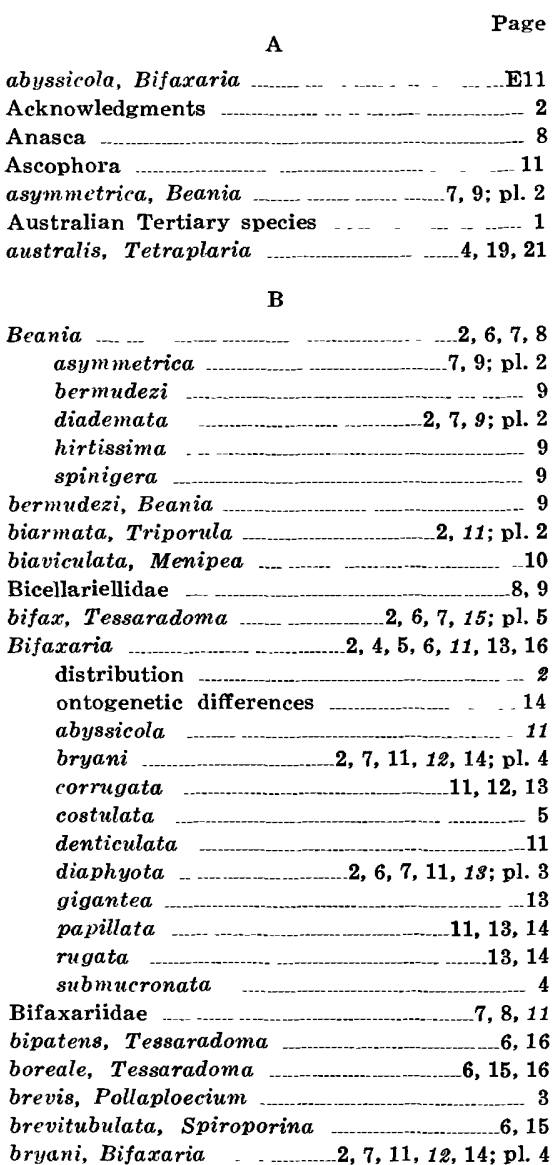

c

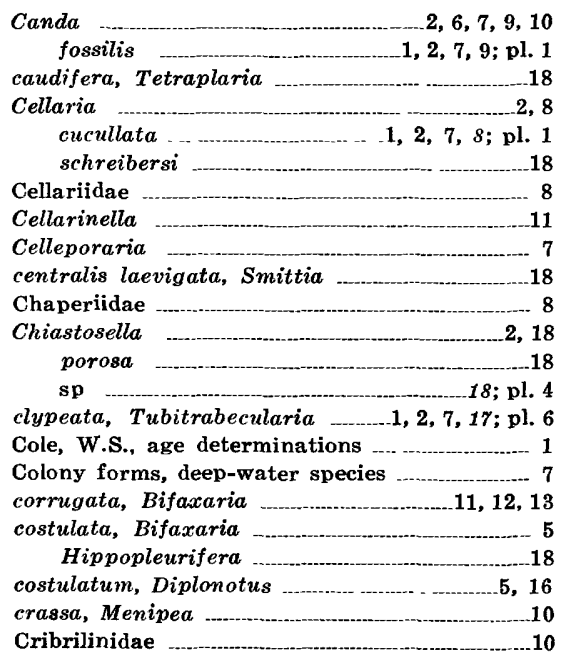

$\begin{array}{lr} & \text { Page } \\ \text { Cryophilic genera } & \text { E2 } \\ \text { Cyclostome Bryozon } & 2\end{array}$

Cyclostome Bryozoa
cucullata, Cellaria

D Deep-water species, characteristics $\ldots 2,15 ; \mathrm{pl} .5$
deliqua, Spiroporina denticulata, Bifaxaria diademata, Beania $2,7,9 ; \mathrm{pl} .2$ diaphyota, Bifaxaria dichotoma, Tetraplaria ...._.............. 4, 18

Diplonotos 16

costulatum
striatum striatum

E

elevata, Tubitrabecularia

elongata, Menipea 16

10

Eschara gracilis

Eua, geology . . . III relation to Tonga Trench …_................

Euginoma _._. 8

Eurybathic genera 2

Eurythermal genera

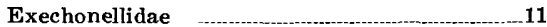

\section{F}

Farciminariidae 8

Faunal element, allochthonous ....................... autochthonous $\quad 6,7$

Tongan cheilostome ....................... 6

Figularia kenleyi $\quad 10,11$ sp

Foreword, by H. S. Ladd ..._____ III

Fossil collection, Eua, Tonga

fossilis, Canda $1,2,7,9, \mathrm{pl}$.

\section{G}

Geographic ranges, Tongan Bryozoa gigantea, Bifaxaria gilbertensis, Pollaploecium Thertensis, Pollaploecium
Tetraplaria Globigerina gortanii _..._............................. gortanii, Globigerina 1 gracilis, Eschara Porina

\section{H, I}

Hippopleurifera costulata hirtissima, Beania _.___._. 9 Hoffmeister, J.E., cited _._-_._IV inimersa, Tetraplaria innocua, Menipea $1,2,7,10 ; \mathrm{pl} .2$

\section{$\mathbf{K}$}

kenleyi, Figularia

Kondo, Yoshio, cited 10,11 kondoi, Spiroporina $2,6,8,14 ; \mathrm{pl}, 4$

\section{L}

lacvigata, Smittea

Ladd, H. S., Foreword laevigata, Smittia centralis $\begin{array}{lr} & \text { Page } \\ \text { Lithothamnium } & \ldots\end{array}$ longicollis, Spiroporina

\section{M}

macgillivrayi, Schizoporella ______._. 17; pl. 5 Melson, William, cited

Menipea

2,10

biaviculata

crassa 10

elongata

innocua 1, $1,7,10 ; \mathrm{pl} .2$

retrorsa -................-10

Morphology, deep-water species ..... 7

$\mathbf{N}, \mathbf{O}$

Nellia

7
4,18

obesa, Tetraplaria

Ontogenetic differences, deep-water species .... 7

Paleoenvironments papillata, Bifaxaria Patsyella $\quad$ sp $\ldots . . .8 ;$ pl. 1 pedunculata, Tetraplaria ... _............. 4, 21 petila, Tetraplaria $\ldots, 18$ Pollaploecium brevis ........... -... ......... - ... 3

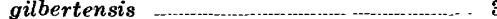
Poricellaria . . . Porina - . 14 gracilis ... .. tubulifera porosa, Chiastosella proditor, Tubitrabecularia

References cited 22 Reteporellina

$2,6,8,17$

sp $\quad 2,17 ;$ pl. 6 retrorsa, Menipea .. ...................... 10 rugata, Bifaxaria

$\mathbf{S}$

Schizoporella 2,17 macgillivrayi Schizoporellidae ..... ...___ 17 schreibersi, Cellaria Sclerodomidae -............ $5,11,12$ Sclerodomus
Serupocellariidae Semihaswellia -... ...- 6 Sertellidae $\ldots$ 2, 4, 19; pl. simata, Tetraplaria
Siphonicytara Siphonicytaridae

Smittea lacvigata Smittia centralis laevigata spinigera, Beania ... Spiroporina brevitubulata deliqua kondoi $2,6,8,14 ;$ pl. 4 longicollis _..._. 6,15 vertebralis
roporinidae 


\section{INDEX}

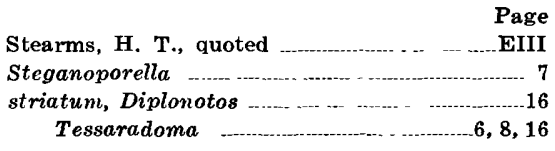

submucronata, Bifaxaria

Systematic paleontology

\section{T, U, V}

Tele-a-hiva Temperature tolerances, Tongan Bryozoa ..... 2 Tessaradoma ......... 2, 6, 15 distribution ontogenetic differences _._..... 16 bifax …. 2, 6, 7, 15; pl. 5 bipatens .......................... 6,16

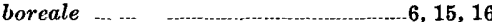
striatum _....................... $6,8,16$ Tetraplaria $\quad 2,3,4,6,7,18,21,22$ astogenetic differences

21

\begin{tabular}{|c|}
\hline $\begin{array}{cc} & \text { Page } \\
\ldots & \text { E21 }\end{array}$ \\
\hline 2 \\
\hline positional polymorphism \\
\hline $\begin{array}{l}\text { australis } \\
\text { caudifera }\end{array}$ \\
\hline $3,4,18$ \\
\hline gilbertensis 18 \\
\hline $\begin{array}{lll}3,18 & -3\end{array}$ \\
\hline obesa \\
\hline pedunculata \\
\hline petila 4,18 \\
\hline simata $2,4,19 ; \mathrm{pl} .7$ \\
\hline tuberculata 4,18 \\
\hline turgida \\
\hline veleroae 3 \\
\hline ventricosa $\ldots \ldots \ldots \ldots$ \\
\hline $\begin{array}{r}4 \\
\text { raplariidae }\end{array}$ \\
\hline rella \\
\hline
\end{tabular}

Thermophilic genera
Page
species

Todd, Ruth, age determinations

Triporula

$2,6,7$,

biarmata ... 2, 11; pl. 2

verrucosa

tuberculata, Tetraplaria

Tubiporella .................. 6

Tubitrabecularia

clypeata $\quad 1,2,7,17 ;$ pl. 6

elevata _..._.

proditor -...

tubulifera, Porina

turgida, Tetraplaria - $1,2,4,21$

Urceolipora _... - ... -

Vaingana _. III, I

veleroae, Tetraplaria

ventricosa, Tetraplaria _____...3, 4, 18, 22

verrucosa, Triporula ... ..... _. 11

vertebralis, Spiroporina 


\section{PLATES I-7}

[Contact photographs of the plates in this report are available, at cost, from U.S. Geological

Survey Library, Federal Center, Denver, Colorado 80225] 


\section{PLATE 1}

[All figures $\times 50$; specimens coated with ammonium chloride]

FIgURES 1, 2. Canda fossilis Waters (p. E9).

1. Frontal (a), basal (b), and left-frontal (c) views of unbranched zoarial fragment showing zooecia with prominent scutum attachments and vibracula with curved rostral channels and large rootle ${ }^{+}$foramina; USNM 169235, sample 2.

2. Frontal (a), basal (b), and right-lateral (c) views of dichotomous zoarial fragment; proximal zooecia have frontal avicularia; two most distal, broken zooecia are inner members of branches (Harmer's (1923) zooecia $\mathrm{F}$ and $\mathrm{G}$ ), meet above axillary zooecium (zooecium $\mathrm{E}$ ) in basal view, and have basal vibracula; vibracula lie on interzooecial suture; USNM 169236, sample 2.

3. Patysella? sp. (p. E8).

Frontal views of zoarial fragment, showing ovicelled (a) and nonovicelled (b) zooecia; small occlusor-laminae are visible below distolateral portions of opesiae; USNM 169232, sample 1.

4. Cellaria cucullata MacGillivray (p. E8).

Frontal views of a zooecial series terminating at distal end of internode (a) and of one intersecting the joint (b) ; USNM 169233; sample 1. 


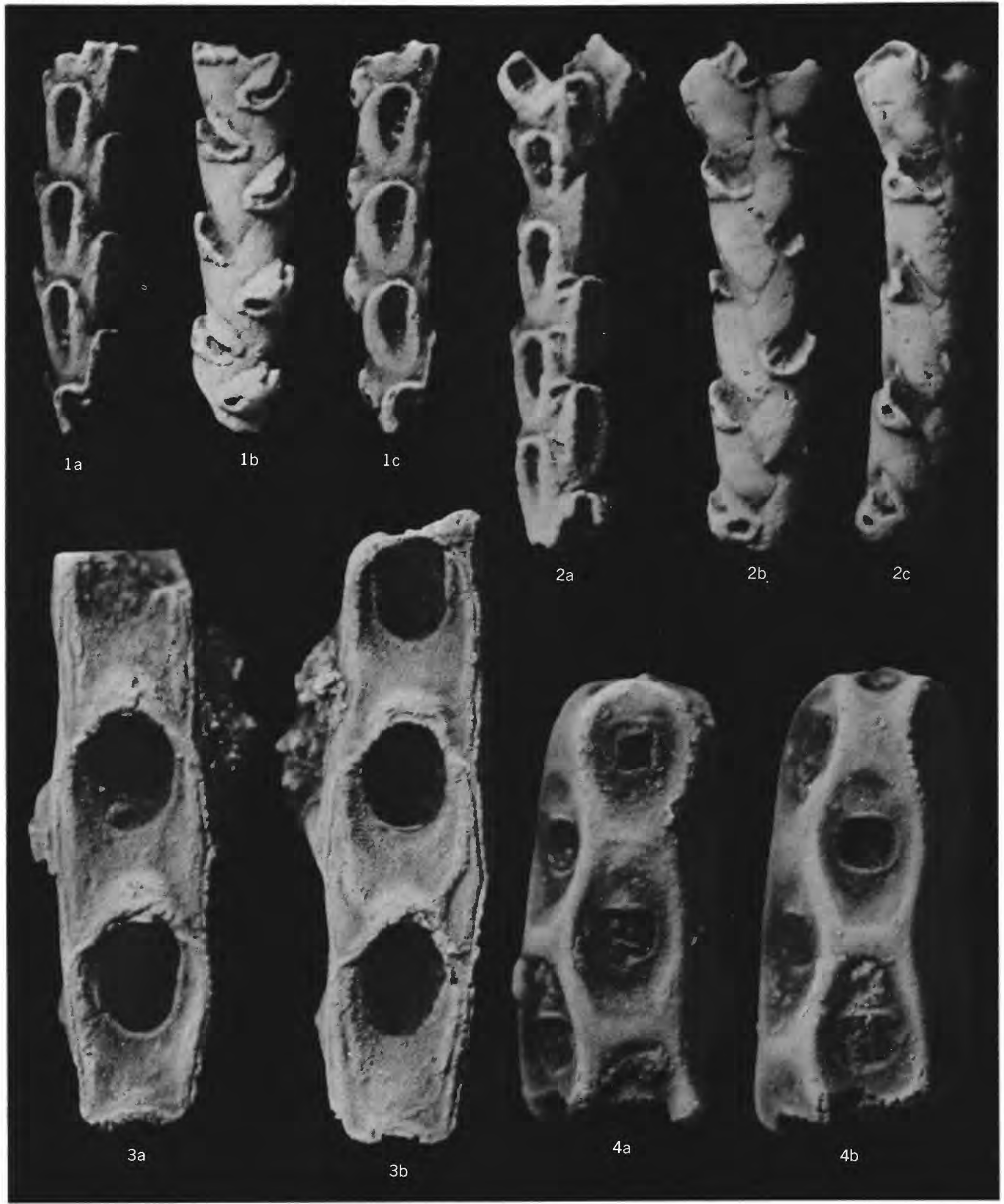




\section{PLATE 2}

[All figures $\times 50$; specimens coated with ammonium chloride]

FIGURE 1. Figularia? sp. (p. E10).

Frontal views of zoarial fragment, showing ovicelled (proximal zooecium, a) and nonovicelled (distal zooecium, a; b) zooecia; bases of spines (?) and costae (fused in right proximal zooecium shown in profile, b) and avicularia; USNM 169239, sample 2.

2. Menipea innocua Waters (p. E10).

Basal (a) and frontal (b) views of branched zoarial fragment showing long, laterally directed avicularia with proximal foramina placed on gymnocysts of biserially arranged zooecia; USNM 169238, sample 2.

3. Beania diademata, n. sp. (p. E9).

Basal (a) and frontal (b) views of zoarial fragment; small fenestrae show only basally among six connecting tubes for each zooecium; spine bases appear on mural rims, around distolateral margins, and on basal surfaces of zooecia; larger, unilateral (probable) base of avicularium shows on each zooecium just proximal to oral end; holotype, USNM 169234 ; sample 2.

4. Triporula aff. T. biarmata (Waters) (p. E11).

Frontal view of encrusting zoarium showing irregularly arranged zooecia and apparent growing margin of colony (top of view); USNM 169240, sample 2. 


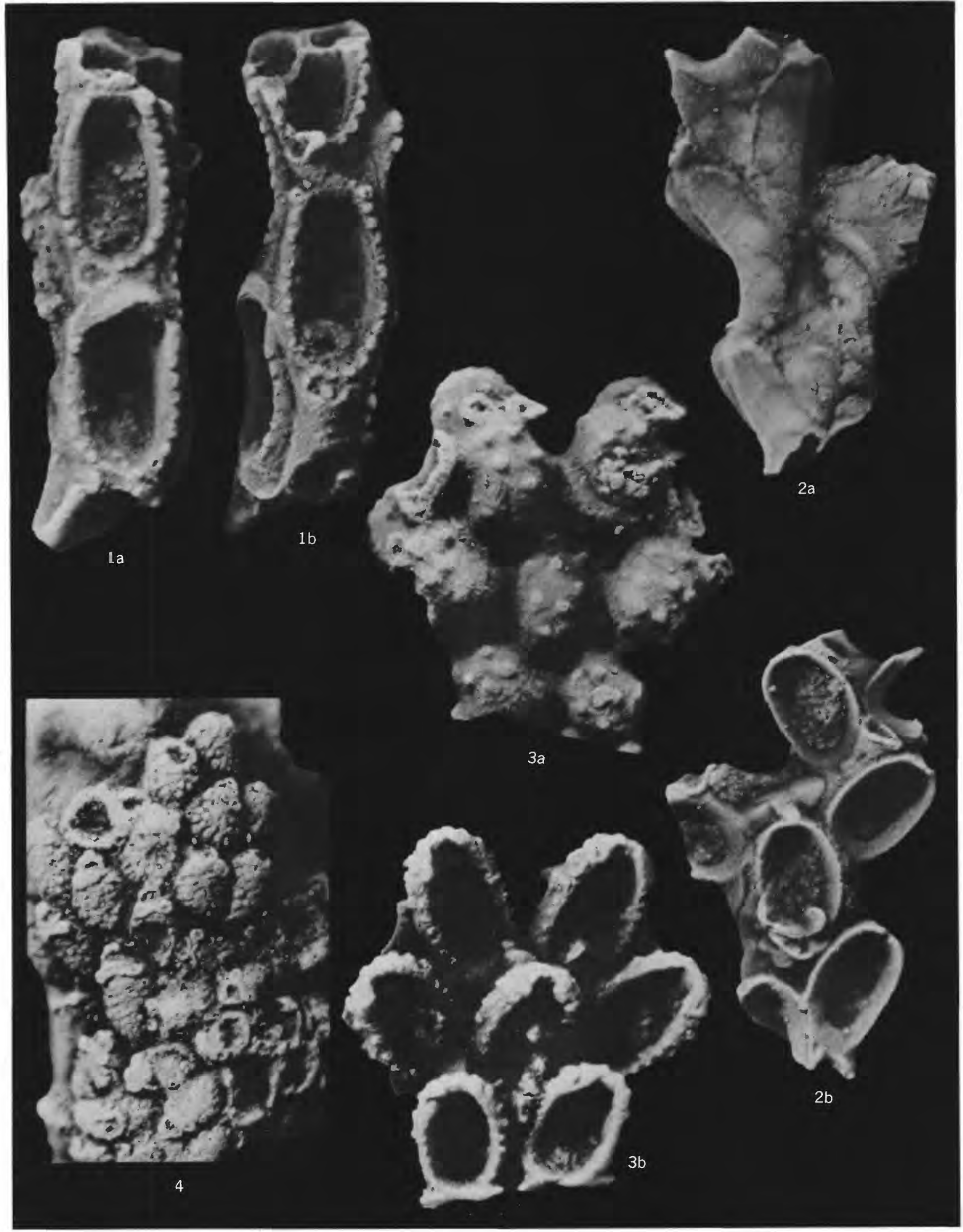




\section{PLATE 3}

[All figures $\times 50$; specimens coated with ammonium chloride]

Figures 1-7. Bifaxaria diaphyota, n. sp. (p. E13).

1. Frontal view of zoarial fragment apparently from intermediate part of colony, showing median frontal furrow, bilaterally disposed frontal avicularia, and surface pitting; paratype, USNM 169246; sample 1.

2. Lateral view of zoarial fragment apparently from distal part of colony, showing interzooecial groove, lateral row of avicularia, striation-like pattern of fine pits, scattered frontal pores; holotype, USNM 169245 ; sample 1.

3. Frontal view of zoarial fragment apparently from proximal part of colony, showing one pair of lateraloral avicularia (in middle orifice), numerous frontal avicularia and broken base of branch; paratype USNM 169247; sample 1.

4,5. Lateral views of zoarial fragments apparently from proximal parts of colonies, showing broken bases of opposing branches and extreme development of frontal avicularia; paratypes, USNM 169248, 169249 ; sample 1.

6, 7. Frontal views of zoarial fragments apparently from proximal parts of colonies, showing extreme development of frontal avicularia; paratypes, USNM 169250, 169251; sample 1. 


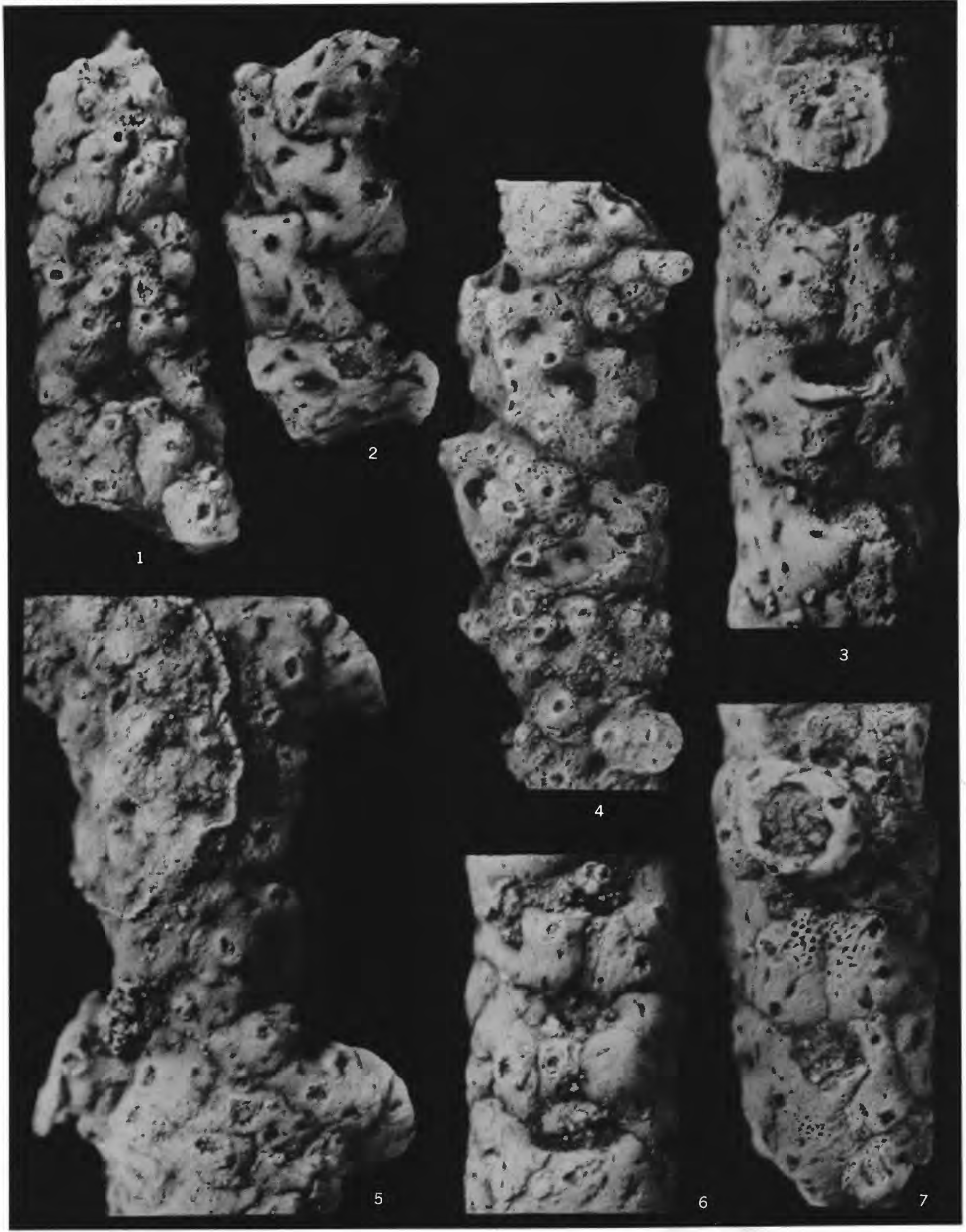




\section{PLATE 4}

[All figures $\times 50$; specimens coated with ammonium chloride]

FIGURES 1, 2. Spiroporina kondoi, n. sp. (p. E14).

1. Oblique frontal view of two zooecial series showing broken peristomes with proximolateral pores, spiramina, and frontal pores; holotype, USNM 169255, sample 1.

2. Frontal view of zoarial fragment preserving bifurcation; paratype, USNM 169257, sample 1.

3. Chiastosella? sp. (p. E18).

Frontal view of encrusting zoarial fragment, showing one nearly complete zooecium and parts of four others; that on right is possibly ovicelled; USNM 169275, sample 2.

4, 5. Bifaxaria bryani, n. sp. (p. E12).

4. Frontal (a) and lateral (b) views of zoarial fragment apparently from distal part of colony, showing stem with broken unopposed branch, at base of which are lateral avicularia; holotype, USNM 169241, sample 2.

5. Lateral (a) and frontal (b) views of zoarial fragment apparently from proximal part of colony, showing approximately aligned lateral avicularia and swellings indicating possible ovicells; paratype, USNM 169242, sample 2 . 


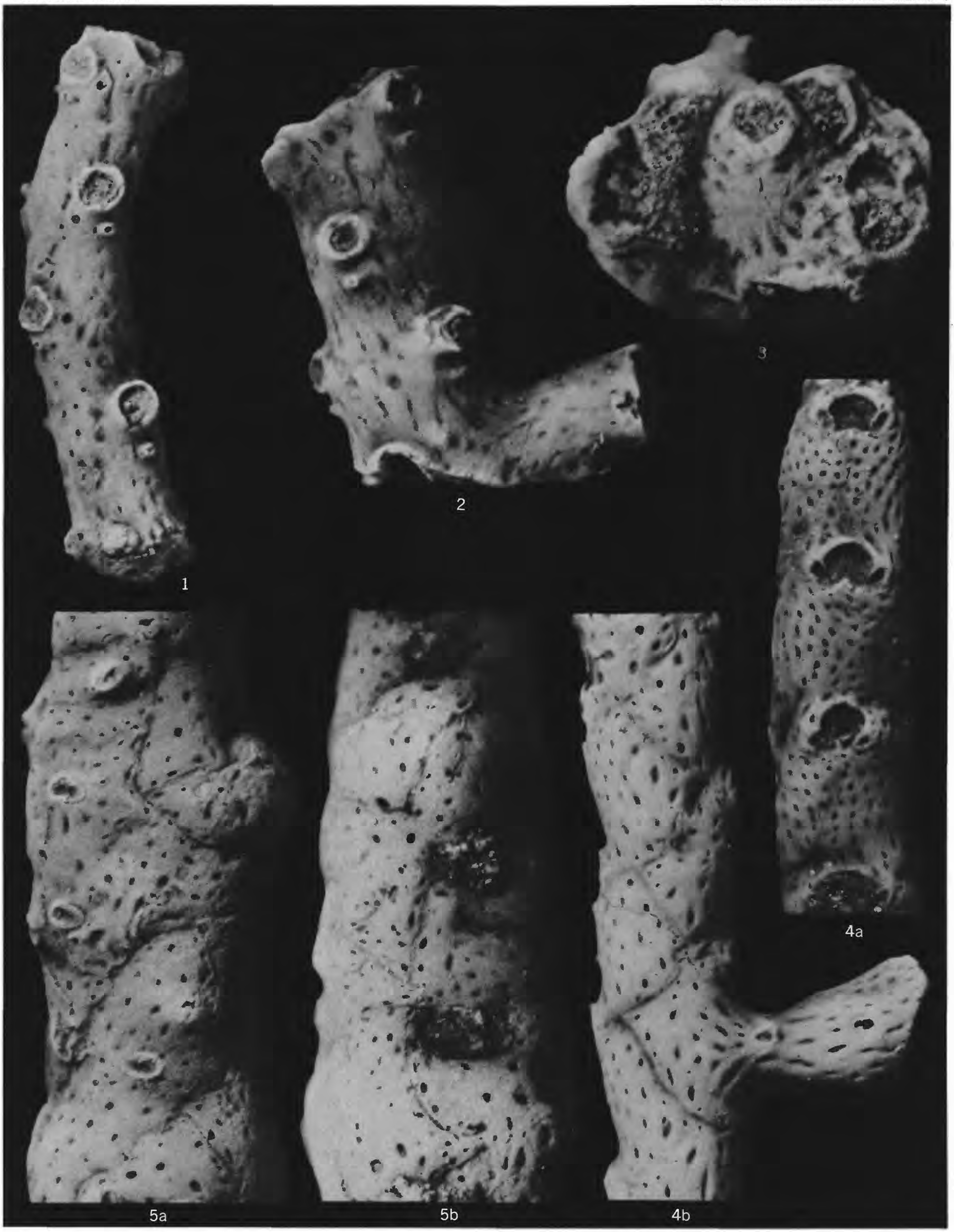




\section{PLATE 5}

[All figures $\times 50$; specimens coated with ammonium chloride]

FIguRES 1, 2. Spiroporina deliqua, n. sp. (p. E15).

1. Frontal (a) and distal (b) views of abraded zoarial fragment preserving growing tip; paratype, USNM 169261 ; sample 1.

2. Frontal view of parts of four whorls of zooecia separated by shallow grooves with V-shaped lobes directed proximally between peristomes; frontal avicularium in one proximal lobe; holotype, USNM 169260, sample 1.

3. Schizoporella aff. S. macgillivrayi Canu and Bassler (p. E17).

Frontal view of subcylindrical zoarial fragment; USNM 169273, sample 1.

4,5. Tessaradoma bifax, n. sp. (p. E15).

4. Frontal (a) and lateral (b) views of zoarial fragment apparently from proximal part of colony, showing nonsinuate secondary orifices and imperforate frontal surfaces; paratype, USNM 169264, sample 1.

5. Lateral (a) and frontal (b) views of zoarial fragment apparently from distal part of colony, showing sinuate secondary orifices, apparently marginal pores, and lateral avicularia; holotype, USNM 169263, sample 2. 


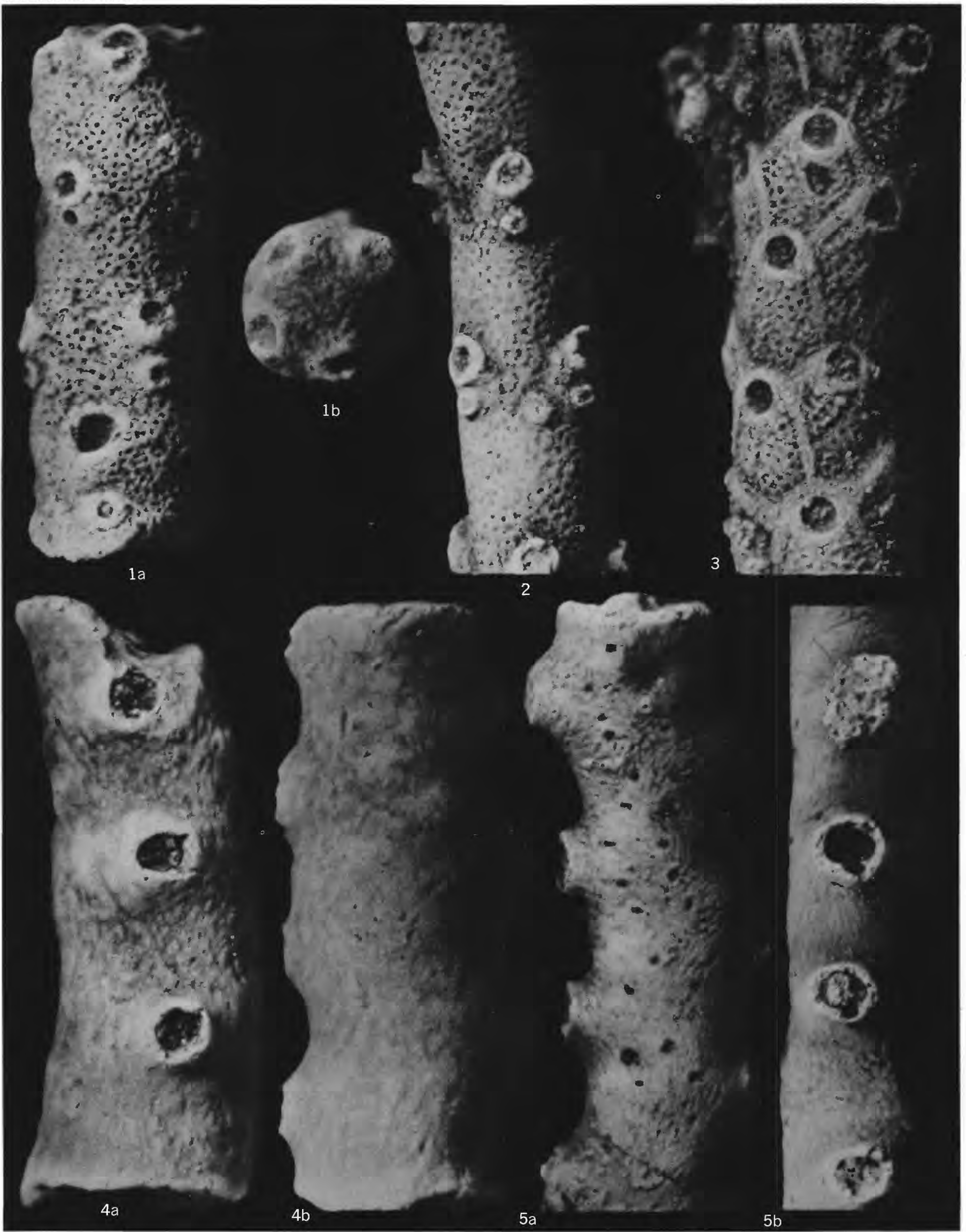




\section{PLATE 6}

[All figures $\times 50$; specimens coated with ammonium chloride]

Figures 1, 3, 4. Reteporellina? sp. (p. E17).

1. Frontal (a) and basal (b) views of quadriserial, ovicelled zoarial fragment, showing broken ovicells, frontal avicularia, and nearly smooth basal surface; USNM 169268, sample 1.

3. Basal view of nonovicelled, quadriserial zoarial fragment, showing two bifurcations; USNM 169269, sample 2.

4. Frontal (a) and basal (b) views of nonovicelled, biserial zoarial fragment, showing biperforateappearing secondary orifices, tuberculate basal surface with one transverse ridge, and two basal avicularia in axils; USNM 169270, sample 2.

2. Tubitrabecularia clypeata (Waters) (p. E17).

Frontal view of zoarial fragments showing elongate zooecia divided at tubular ascopore collar into subequal proximal and peristomal areas; faint longitudinal ridge on peristome; and paired lateral-oral avicularia with complete crossbars; USNM 169266, sample 1. 


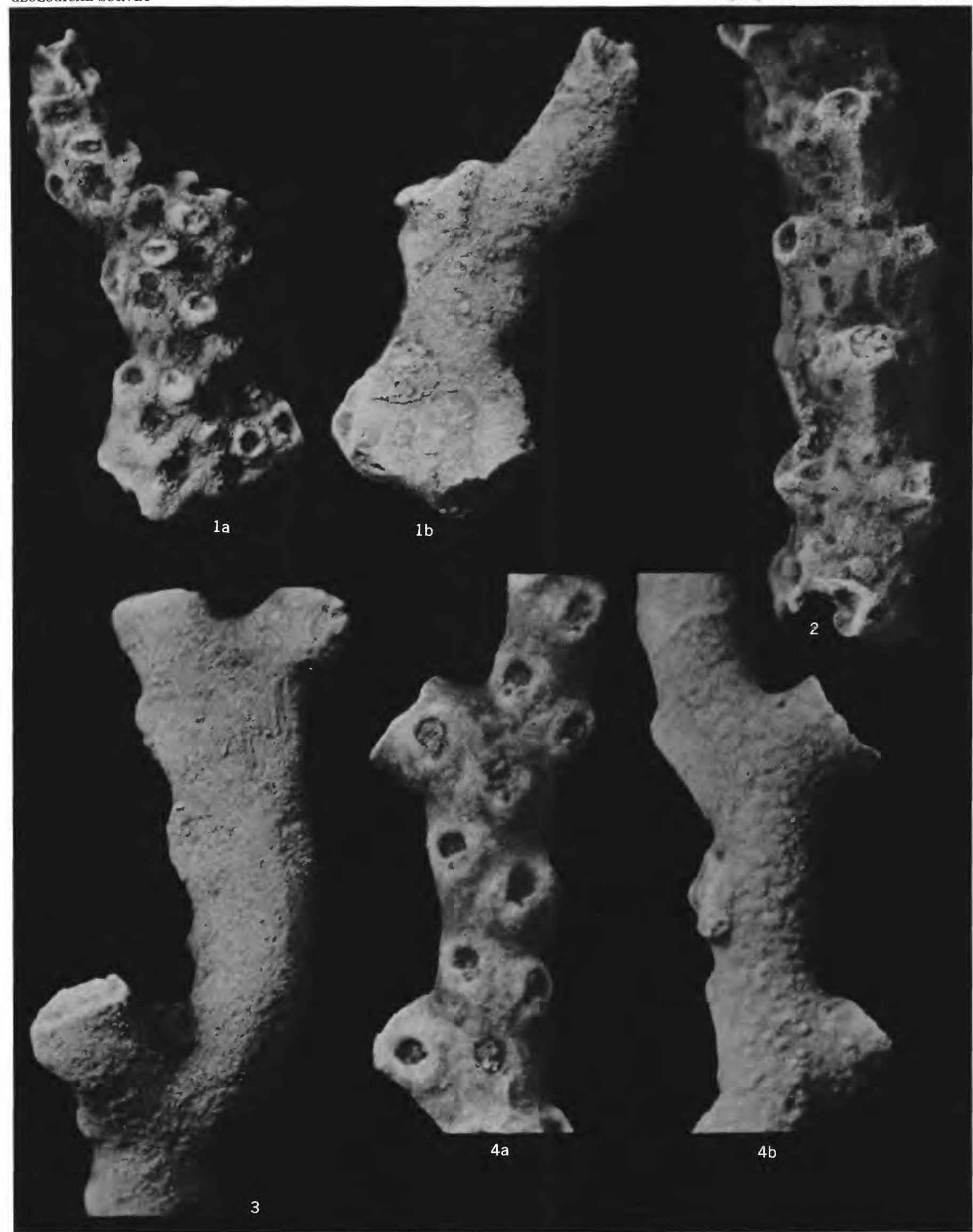




\section{PLATE 7}

[All figures $\times 50$; specimens coated with ammonium chloride]

FiguRes 1, 4, 5. Tetraplaria simata, n. sp. (p. E19).

1. Frontal views of zooecia of first, third, and fifth pairs (a) and of second and fourth pairs (b) of complete, abraded internode; paratype, USNM 169277, sample 2.

4. Frontal views of zooecia of first, third, and fifth pairs (a) and of second and fourth pairs (b) of complete, ovicelled internode; holotype, USNM 169276, sample 2.

5. Frontal views of zooecia of first, third, and fifth pairs (a) and of second and fourth pairs (b) of complete internode; paratype, USNM 169278, sample 1.

2, 3. Tetraplaria cf. T. turgida Tewari and Srivastava (p. E21).

2. Frontal views of zooecia of second and fourth pairs (a) and of first, third, and fifth pairs (b) of complete, ovicelled internode; USNM 169280, sample 2.

3. Frontal views of zooecia of second pair (a) and of first and third pairs (b) of nearly complete internode; USNM 169281, sample 2. 


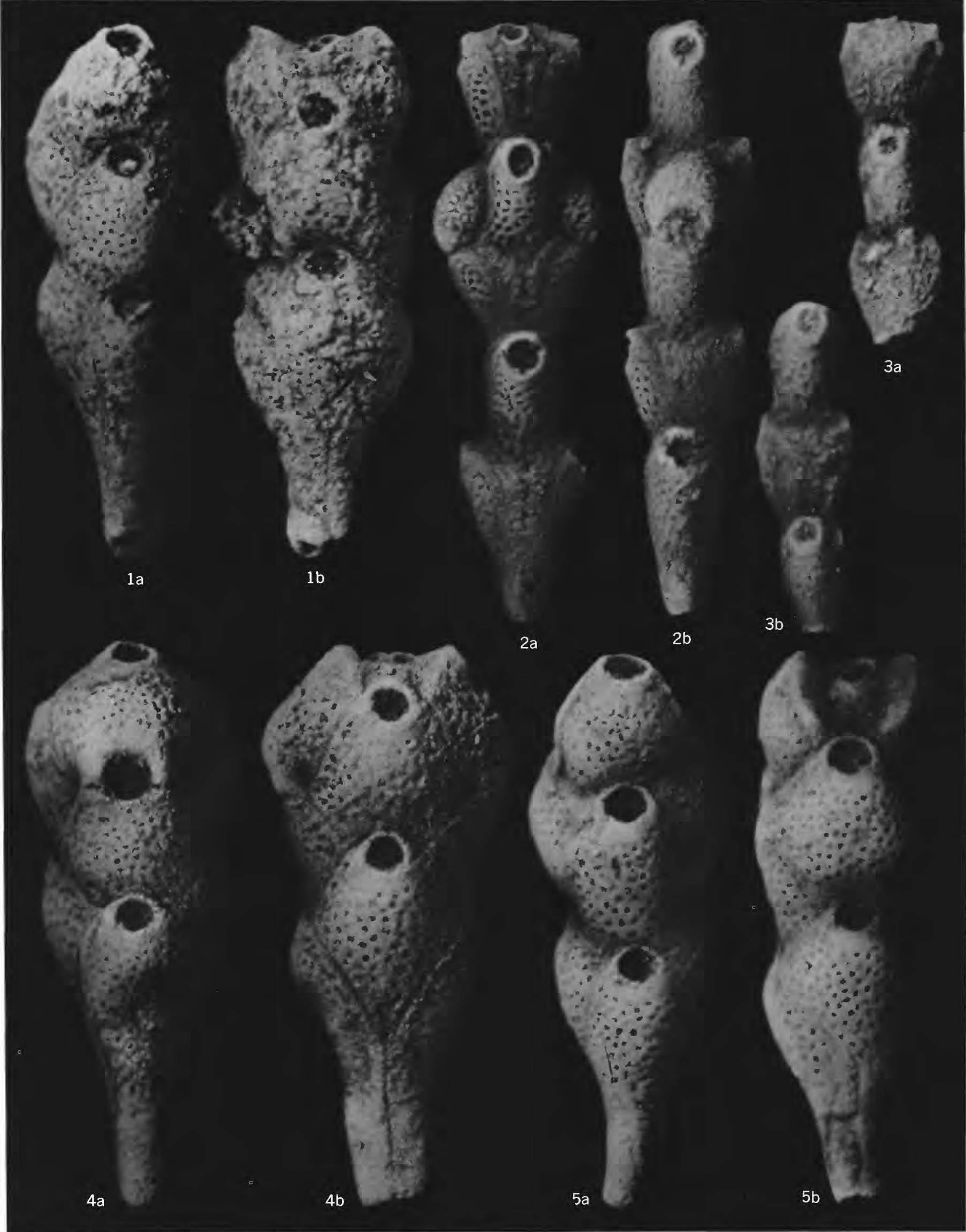


